\title{
Factors controlling plankton community production, export flux, and particulate matter stoichiometry in the coastal upwelling system off Peru
}

Lennart Thomas Bach ${ }^{1}$, Allanah Joy Paul ${ }^{2}$, Tim Boxhammer ${ }^{2}$, Elisabeth von der Esch ${ }^{3}$, Michelle Graco Kai Georg Schulz ${ }^{5}$, Eric Achterberg ${ }^{2}$, Paulina Aguayo ${ }^{6}$, Javier Arístegui ${ }^{7}$, Patrizia Ayón ${ }^{4}$, Isabel Baños ${ }^{7}$, Avy Bernales ${ }^{4}$, Anne Sophie Boegeholz ${ }^{8}$, Francisco Chavez ${ }^{9}$, Gabriela Chavez ${ }^{9}$, Shao-Min Chen ${ }^{2,10}$, Kristin Doering ${ }^{2,10}$, Alba Filella ${ }^{2}$, Martin Fischer ${ }^{8}$, Patricia Grasse ${ }^{2,11}$, Mathias Haunost ${ }^{2}$, Jan Hennke , $^{2}$ Nauzet Hernández-Hernández ${ }^{7}$, Mark Hopwood ${ }^{2}$, Maricarmen Igarza ${ }^{12}$, Verena Kalter ${ }^{2,13}$, Leila Kittu ${ }^{2}$, Peter Kohnert $^{2}$, Jesus Ledesma ${ }^{4}$, Christian Lieberum ${ }^{2}$, Silke Lischka ${ }^{2}$, Carolin Löscher ${ }^{14}$, Andrea Ludwig ${ }^{2}$, Ursula Mendoza ${ }^{4}$, Jana Meyer ${ }^{2}$, Judith Meyer ${ }^{2}$, Fabrizio Minutolo ${ }^{2}$, Joaquin Ortiz Cortes ${ }^{2}$, Jonna Piiparinen ${ }^{15}$, Claudia Sforna $^{2}$, Kristian Spilling ${ }^{15,16}$, Sonia Sanchez ${ }^{4}$, Carsten Spisla ${ }^{2}$, Michael Sswat ${ }^{2}$, Mabel Zavala Moreira ${ }^{17}$, and Ulf Riebesell ${ }^{2}$

${ }^{1}$ Institute for Marine and Antarctic Studies, University of Tasmania, Hobart, Tasmania, Australia

${ }^{2}$ GEOMAR Helmholtz Centre for Ocean Research Kiel, Kiel, Germany

${ }^{3}$ Institute of Hydrochemistry, Chair of Analytical Chemistry and Water Chemistry,

Technical University of Munich, Munich, Germany

${ }^{4}$ Direccióìn General de Investigaciones Oceanográficas y Cambio Climático,

Instituto del Mar del Perú (IMARPE), Callao, Peru

${ }^{5}$ Centre for Coastal Biogeochemistry, School of Environment, Science and Engineering,

Southern Cross University, Lismore, New South Wales, Australia

${ }^{6}$ Millennium Institute of Oceanography (IMO), Universidad de Concepción, Concepción, Chile

${ }^{7}$ Instituto de Oceanografía y Cambio Global, IOCAG, Universidad de Las Palmas de Gran Canaria ULPGC,

Las Palmas, Spain

${ }^{8}$ Institute of General Microbiology, Department of Biology, Christian-Albrechts-Universität zu Kiel, Kiel, Germany

${ }^{9}$ Monterey Bay Aquarium Research Institute, Moss Landing, United States of America

${ }^{10}$ Department of Earth and Environmental Sciences, Dalhousie University, Halifax, Canada

${ }^{11}$ German Centre for Integrative Biodiversity Research (iDiv), Halle-Jena-Leipzig, Germany

${ }^{12}$ Programa de Maestría en Ciencias del Mar, Universidad Peruana Cayetano Heredia, Lima, Peru

${ }^{13}$ Department of Ocean Sciences, Memorial University of Newfoundland, Logy Bay, Newfoundland, Canada

${ }^{14}$ University of Southern Denmark, Odense, Denmark

${ }^{15}$ Marine Research Centre, Finnish Environment Institute, Helsinki, Finland

${ }^{16}$ Faculty of Engineering and Science, University of Agder, Kristiansand, Norway

${ }^{17}$ Escuela Superior Politécnica del Litoral, Guayaquil, Ecuador

Correspondence: Lennart Thomas Bach (lennart.bach@utas.edu.au)

Received: 1 February 2020 - Discussion started: 18 February 2020

Revised: 28 July 2020 - Accepted: 16 August 2020 - Published: 12 October 2020

Published by Copernicus Publications on behalf of the European Geosciences Union. 
Abstract. Eastern boundary upwelling systems (EBUS) are among the most productive marine ecosystems on Earth. The production of organic material is fueled by upwelling of nutrient-rich deep waters and high incident light at the sea surface. However, biotic and abiotic factors can modify surface production and related biogeochemical processes. Determining these factors is important because EBUS are considered hotspots of climate change, and reliable predictions of their future functioning requires understanding of the mechanisms driving the biogeochemical cycles therein. In this field experiment, we used in situ mesocosms as tools to improve our mechanistic understanding of processes controlling organic matter cycling in the coastal Peruvian upwelling system. Eight mesocosms, each with a volume of $\sim 55 \mathrm{~m}^{3}$, were deployed for $50 \mathrm{~d} \sim 6 \mathrm{~km}$ off Callao $\left(12^{\circ} \mathrm{S}\right)$ during austral summer 2017, coinciding with a coastal El Niño phase. After mesocosm deployment, we collected subsurface waters at two different locations in the regional oxygen minimum zone (OMZ) and injected these into four mesocosms (mixing ratio $\approx 1.5: 1$ mesocosm: $\mathrm{OMZ}$ water). The focus of this paper is on temporal developments of organic matter production, export, and stoichiometry in the individual mesocosms. The mesocosm phytoplankton communities were initially dominated by diatoms but shifted towards a pronounced dominance of the mixotrophic dinoflagellate (Akashiwo sanguinea) when inorganic nitrogen was exhausted in surface layers. The community shift coincided with a short-term increase in production during the $A$. sanguinea bloom, which left a pronounced imprint on organic matter $\mathrm{C}: \mathrm{N}: \mathrm{P}$ stoichiometry. However, $\mathrm{C}, \mathrm{N}$, and $\mathrm{P}$ export fluxes did not increase because $A$. sanguinea persisted in the water column and did not sink out during the experiment. Accordingly, export fluxes during the study were decoupled from surface production and sustained by the remaining plankton community. Overall, biogeochemical pools and fluxes were surprisingly constant for most of the experiment. We explain this constancy by light limitation through selfshading by phytoplankton and by inorganic nitrogen limitation which constrained phytoplankton growth. Thus, gain and loss processes remained balanced and there were few opportunities for blooms, which represents an event where the system becomes unbalanced. Overall, our mesocosm study revealed some key links between ecological and biogeochemical processes for one of the most economically important regions in the oceans.

\section{Introduction}

Eastern boundary upwelling systems (EBUS) are hotspots of marine life (Chavez and Messié, 2009; Thiel et al., 2007). They support around $5 \%$ of global ocean primary production and $20 \%$ of marine fish catch while covering less than $1 \%$ of the ocean surface area (Carr, 2002; Chavez and Messié,
2009; Messié and Chavez, 2015). One of the most productive EBUS is located along the Peruvian coastline between 4 and $16^{\circ} \mathrm{S}$ (Chavez and Messié, 2009). Here, southeasterly trade winds drive upward Ekman pumping and offshore Ekman transport, resulting in upwelling of nutrient-rich subsurface waters (Albert et al., 2010). In the surface ocean, the nutrientrich water is exposed to sunlight, leading to enhanced primary production (Daneri et al., 2000).

This enhanced production has two important outcomes. First, it sustains one of the largest fisheries in the world, making the Peruvian upwelling system an area of outstanding economic value (Bakun and Weeks, 2008; Chavez et al., 2008). Second, the remineralization of large amounts of sinking organic matter from primary production leads to pronounced dissolved-oxygen $\left(\mathrm{dO}_{2}\right)$ consumption in subsurface waters. This local source of oxygen consumption in already $\mathrm{O}_{2}$-depleted subsurface Pacific water masses contributes to what is likely the most pronounced oxygen minimum zone (OMZ) globally (Karstensen et al., 2008).

Upwelling of nutrient-rich water occurs primarily near the coast from where the water is advected net westward (i.e., further offshore but including a pronounced latitudinal advection; Thiel et al., 2007). Primary production changes along this pathway with the highest rates when phytoplankton biomass has reached its maximum in a new patch of upwelled water (Chavez et al., 2002). Primary production generally declines with increasing distance from shore, even though eddies and other mesoscale features can modify this idealized pattern (Bakun and Weeks, 2008; Stramma et al., 2013; Thiel et al., 2007). Plankton community composition changes in accordance with the changes in primary production. Diatoms and herbivorous mesozooplankton often prevail near the coast, but the community transitions towards Crypto-, Hapto-, Prasino-, and Cyanophyceae and a more carnivorous mesozooplankton community further offshore (Ayón et al., 2008; DiTullio et al., 2005; Franz et al., 2012a; Meyer et al., 2017). Dinoflagellates also play an important role, especially when upwelling relaxes and nutrient concentrations decrease (Smayda and Trainer, 2010). The composition of plankton communities is closely linked to key biogeochemical processes such as organic matter production and export (Boyd and Newton, 1999; González et al., 2009; Longhurst, 1995). Thus, observed patterns of production and export in the Peruvian upwelling system (and elsewhere) can only be understood when the associated links to the plankton community structures are revealed. Establishing and quantifying these links is particularly important for the Peruvian upwelling system, considering that this region is disproportionately affected by climate change (Gruber, 2011) and alterations in production could disrupt one of the largest fisheries in the world (Bakun and Weeks, 2008).

In austral summer 2017 (coinciding with a strong coastal El Niño phase), we set up an in situ mesocosm experiment in the coastal Peruvian upwelling system off Callao to gain mechanistic understanding of how biological processes in the 
plankton community influence biogeochemical processes. Our two primary questions were as follows: (1) how do plankton community structure and associated biogeochemical processes change following an upwelling event? This first question was addressed by simply monitoring the developments within the mesocosms for a $50 \mathrm{~d}$ period. (2) How does upwelling of water masses with different OMZ signatures influence plankton succession and pelagic biogeochemistry? This second question was addressed by adding two types of subsurface water with different nutrient stoichiometries to four mesocosms. In the present paper we will focus on the first question and target three ecologically and biogeochemically important measures: organic matter production, export, and stoichiometry. Our paper is the first in a Biogeosciences special issue about the 2017 Peru mesocosm campaign. It includes a comprehensive description of the setup and aims to synthesize some of the key results of the study.

\section{Methods}

\subsection{Mesocosm deployment and maintenance}

On 22 February 2017, eight Kiel Off-Shore Mesocosms for Future Ocean Simulations (KOSMOS, M1-M8; Riebesell et al., 2013) were deployed with Buque Armada Peruana Morales (BAP Morales) in the SE Pacific, $6 \mathrm{~km}$ off the Peruvian coastline $\left(12.0555^{\circ} \mathrm{S}, 77.2348^{\circ} \mathrm{W}\right.$; Fig. 1). The water depth at the deployment site was $\sim 30 \mathrm{~m}$, and the area was protected from southern and southwestern swells by San Lorenzo Island (Fig. 1). The mesocosms consisted of cylindrical, $18.7 \mathrm{~m}$ long polyurethane bags $(2 \mathrm{~m}$ diameter, $54.4 \pm 1.3 \mathrm{~m}^{3}$ volume; Table 1) suspended in $8 \mathrm{~m}$ tall flotation frames (Fig. 1). The bags were initially folded so that the flotation frames and bags could be lifted with the crane from BAP Morales into the water where the mesocosms were moored with anchor weights. The bags were unfolded immediately after deployment with the lower end extending to $\sim 19.7 \mathrm{~m}$ and the upper end $1 \mathrm{~m}$ below the surface. Nets (mesh size $3 \mathrm{~mm}$ ) attached to both ends of the bags allowed water exchange but prevented larger plankton or nekton from entering the mesocosms. On 25 February, the mesocosms were sealed when divers replaced lower meshes with sediment traps, while upper ends of the bags were pulled $\sim 1.5 \mathrm{~m}$ above the sea surface immediately after sediment trap attachment. These two steps isolated the water mass enclosed inside the mesocosms from the surrounding Pacific water and marked the beginning of the experiment (Day 0; Fig. 2). After the closure, the enclosed water columns were $\sim 19 \mathrm{~m}$ deep of which the lowest $2 \mathrm{~m}$ were the conical sediment traps (Fig. 1).

The mesocosm bags were regularly cleaned from the inside and on the outside to minimize biofouling (Fig. 2). Cleaning the outside of the bags was carried out with brushes, either from small boats $(0-1.5 \mathrm{~m})$ or by divers $(1.5-$

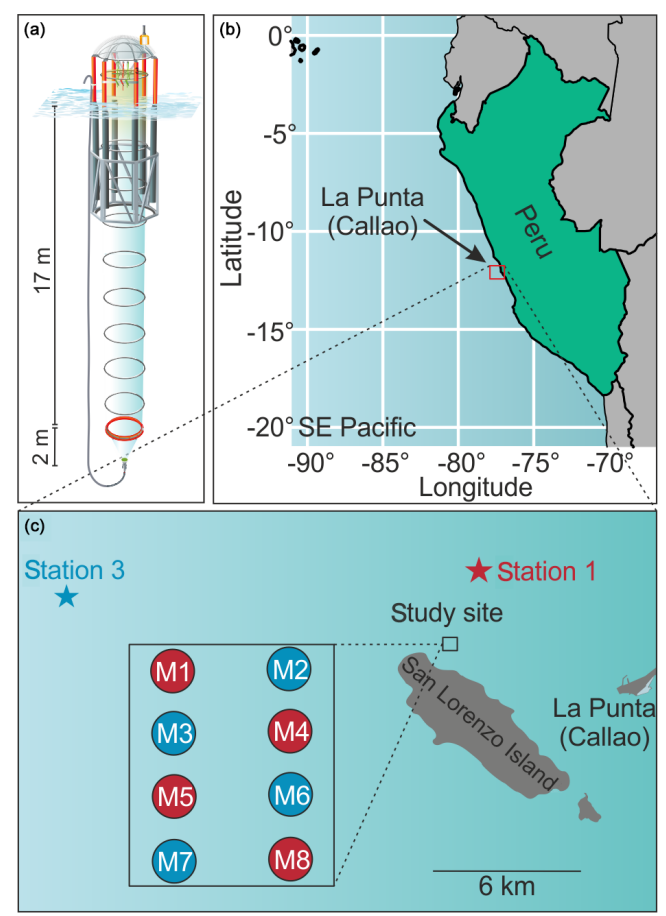

Figure 1. The mesocosm study site. (a) Graphic of one KOSMOS unit with underwater bag dimensions given on the left. We acknowledge reprint permission from the AGU as parts of this drawing was used for a publication by Bach et al. (2016b). (b) Overview map of the study region. Please note that the square marking the study site is not true to scale. (c) Detailed map of the study site. The laboratories for sample processing were located in La Punta (Callao). The study site was located at the northern end of San Lorenzo Island. The mesocosm arrangement is shown in the additional square. The stars mark the locations of stations 1 and 3, where the two different $\mathrm{OMZ}$ water masses were collected. Coordinates of relevant sites are given in Sect. 2.1.

$8 \mathrm{~m})$. The inner sides of the bags were cleaned with rubber blades attached to a polyethylene ring which had the same diameter as the mesocosm bags and was ballasted with a $30 \mathrm{~kg}$ weight (Riebesell et al., 2013). The rubber blades were pushed against the walls by the ring and scraped off the organic material while sliding downwards. Cleaning inside down to $\sim 1 \mathrm{~m}$ above the sediment traps was conducted approximately every eighth day to prevent biofouling at an early stage of its progression.

\subsection{OMZ water addition to the mesocosms}

On 2 and 7 March 2017 (days 5 and 10), we collected two batches of OMZ water $\left(100 \mathrm{~m}^{3}\right.$ each) with Research Vessel IMARPE VI at two different stations of the Instituto del Mar del Perú (IMARPE) time-series transect (Graco et al., 2017). The first batch was collected on Day 5 at station 1 $\left(12.028323^{\circ} \mathrm{S}, 77.223603^{\circ} \mathrm{W}\right)$ at a depth of $30 \mathrm{~m}$. The second was collected on Day 10 at station $3\left(12.044333^{\circ} \mathrm{S}\right.$, 
Table 1. Nutrient concentrations at the beginning of the experiment and after the OMZ water addition as well as the mesocosm volumes at the end of the experiment. The color code identifies the "low N/P" treatment (blue) and the "very low N/P" treatment (red). $\left(\mathrm{N}: \mathrm{P}_{\text {inorg }}=\right.$ $\left.\left(\mathrm{NO}_{x}^{-}+\mathrm{NH}_{4}^{+}\right) / \mathrm{PO}_{4}^{3-}\right)$. The asterisks indicate significantly different $(p<0.05)$ conditions between the treatments as was calculated with a two-tailed $t$ test after equal variance was confirmed with an $F$ test.

\begin{tabular}{|c|c|c|c|c|c|c|c|c|c|c|}
\hline & & M1 & M2 & M3 & M4 & M5 & M6 & M7 & M8 & $\begin{array}{l}\text { Pacific } \\
\text { water }\end{array}$ \\
\hline & & - & -1 & - & - & 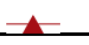 & -1 & $\rightarrow$ & $\nabla$ & - \\
\hline \multirow{7}{*}{$\begin{array}{l}\text { Day } 1 \text { (first } \\
\text { sampling) }\end{array}$} & $\mathrm{NO}_{\mathrm{x}}^{-}\left(\mu \mathrm{mol} \mathrm{L}{ }^{-1}\right)$ & 6.85 & 7.03 & 6.89 & 5.61 & 6.51 & 6.96 & 7.59 & 6.89 & 11.60 \\
\hline & $\mathrm{PO}_{4}^{3-}\left(\mu \mathrm{mol} \mathrm{L}^{-1}\right)$ & 1.61 & 1.91 & 1.58 & 1.39 & 1.75 & 1.85 & 1.97 & 1.88 & 2.19 \\
\hline & $\mathrm{Si}(\mathrm{OH})_{4}\left(\mu \mathrm{mol} \mathrm{L}{ }^{-1}\right)$ & 7.96 & 10.01 & 7.43 & 6.12 & 8.82 & 9.52 & 10.35 & 9.63 & 11.04 \\
\hline & $\mathrm{NH}_{4}^{+}\left(\mu \mathrm{mol} \mathrm{L}{ }^{-1}\right)$ & 5.47 & 4.49 & 4.03 & 2.24 & 2.95 & 3.30 & 4.87 & 3.35 & 5.79 \\
\hline & $\mathrm{N}: \mathrm{P}_{\text {inorg }}(\mathrm{mol}: \mathrm{mol})$ & 7.65 & 6.04 & 6.92 & 5.63 & 5.40 & 5.54 & 6.33 & 5.43 & 7.95 \\
\hline & $\mathrm{DON}\left(\mu \mathrm{mol} \mathrm{L}{ }^{-1}\right)$ & 10.10 & 11.49 & 11.10 & 10.84 & 10.61 & 10.82 & 10.74 & 10.88 & 11.09 \\
\hline & $\mathrm{DOP}\left(\mu \mathrm{mol} \mathrm{L}{ }^{-1}\right)$ & 0.57 & 0.45 & 0.61 & 0.64 & 0.55 & 0.57 & 0.52 & 0.58 & 0.52 \\
\hline \multirow{7}{*}{$\begin{array}{l}\text { Day } 13 \text { (first } \\
\text { sampling } \\
\text { after OMZ } \\
\text { water } \\
\text { addition) }\end{array}$} & $\mathrm{NO}_{\mathrm{x}}^{-}\left(\mu \mathrm{mol} \mathrm{L}^{-1}\right)^{*}$ & 2.17 & 3.60 & 5.51 & 2.05 & 1.96 & 3.81 & 3.29 & 1.14 & 9.68 \\
\hline & $\mathrm{PO}_{4}^{3-}\left(\mu \mathrm{mol} \mathrm{L}{ }^{-1}\right)$ & 1.97 & 2.01 & 2.02 & 1.97 & 2.02 & 2.05 & 1.99 & 2.04 & 2.11 \\
\hline & $\mathrm{Si}(\mathrm{OH})_{4}\left(\mu \mathrm{mol} \mathrm{L}{ }^{-1}\right)$ & 9.31 & 9.49 & 9.54 & 8.56 & 8.36 & 8.68 & 7.47 & 8.04 & 9.61 \\
\hline & $\mathrm{NH}_{4}^{+}\left(\mu \mathrm{mol} \mathrm{L}^{-1}\right)^{*}$ & 1.13 & 1.33 & 2.11 & 1.46 & 0.91 & 2.03 & 1.63 & 1.04 & 2.25 \\
\hline & $\mathrm{N}: P_{\text {inorg }}(\mathrm{mol}: \mathrm{mol}) *$ & 1.67 & 2.45 & 3.77 & 1.79 & 1.42 & 2.85 & 2.48 & 1.07 & 5.66 \\
\hline & $\operatorname{DON}\left(\mu \mathrm{mol} \mathrm{L}^{-1}\right)$ & 8.58 & 4.15 & 7.26 & 8.71 & 7.60 & 8.13 & 7.14 & 3.98 & 9.02 \\
\hline & $\operatorname{DOP}\left(\mu \mathrm{mol} \mathrm{L}{ }^{-1}\right)$ & 0.38 & 0.24 & 0.29 & 0.36 & 0.36 & 0.34 & 0.37 & 0.22 & 0.45 \\
\hline Day 50 & Volume $\left(\mathrm{m}^{3}\right)$ & 54.6 & 55.8 & 54.6 & 56.0 & 54.6 & 52.5 & 52.8 & 54.4 & \\
\hline
\end{tabular}

Mesocosm closure
Manipulation
Q Water removal from mesocosms
Deep water addition
Introduction of scallop larvae
+ Introduction of fish eggs
+ Volume determination

8 Deep water collection

Sampling

- Water column

Sediment trap

* CTD casts

Cleaning

o Inside cleaning

Q Outside cleaning

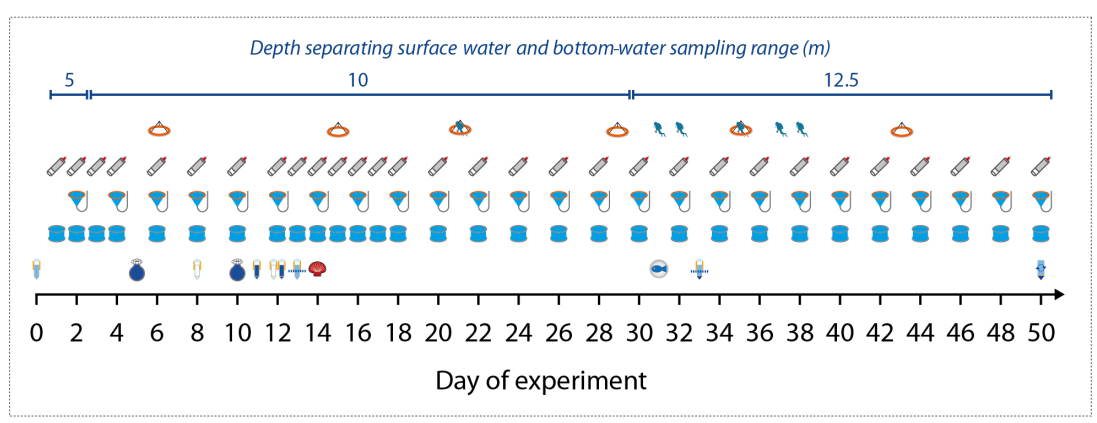

Figure 2. Manipulation, sampling, and maintenance schedule. Day 0 was 25 February 2017, and Day 50 was 16 April 2017. Also given is the depth separating the surface water and bottom-water sampling range of the course of the study.

$77.377583^{\circ} \mathrm{W}$ ) at a depth of $\sim 70 \mathrm{~m}$ (Fig. 1). In both cases we used deep water collectors described by Taucher et al. (2017). The pear-shaped $100 \mathrm{~m}^{3}$ bags of the collector systems consisted of flexible, fiber-reinforced, food-grade, polyvinyl chloride material (opaque). The round openings of the bags $(0.25 \mathrm{~m}$ diameter covered with a $10 \mathrm{~mm}$ mesh) were equipped with a custom-made propeller system that pumped water into the bag and a shutter system that closed the bag when full. Prior to their deployment, the bags were ballasted with a $300 \mathrm{~kg}$ weight so that the bag sank to the desired 
depth. A rope attached to the bag guaranteed that it did not sink deeper. The propeller and the shutter system were timecontrolled and started to fill the bag after it had reached the desired depth and closed the bag after $\sim 1.5 \mathrm{~h}$ of pumping. To recover the collector, the weight was released with an acoustic trigger so that 24 small floats attached to the top made the system positively buoyant and brought it back to the surface. The collectors were towed back to the mesocosm area and moored therein with anchor weights.

On 8 and 9 March 2017 (Day 11 and 12), we exchanged $\sim 20 \mathrm{~m}^{3}$ of water enclosed in each mesocosm with water collected from station 3 (M2, M3, M6, M7) or station 1 (M1, M4, M5, M8). The exchange was carried out in two steps using a submersible pump (Grundfos SP 17-5R, pump rate $\sim 18 \mathrm{~m}^{3} \mathrm{~h}^{-1}$ ). On Day 8, we installed the pump for about 30-40 min in each mesocosm and pumped $9 \mathrm{~m}^{3}$ out of each bag from a depth of 11 to $12 \mathrm{~m}$. On Day 11, the pump was installed inside the collector bags, and $10 \mathrm{~m}^{3}$ of water was injected to a $14-17 \mathrm{~m}$ depth (hose diameter $5 \mathrm{~cm}$ ). Please note that the pump (for water withdrawal) and hose (for water injection) were carefully moved up and down the water column between 14 and $17 \mathrm{~m}$ so that the water was evenly withdrawn from, or injected into, this depth range. On Day 12, we repeated this entire procedure but this time removed $10 \mathrm{~m}^{3}$ from 8 to $9 \mathrm{~m}$ and added $12 \mathrm{~m}^{3}$ evenly to the depth range from 1 to $9 \mathrm{~m}$.

\subsection{Salt additions to control stratification and to determine mesocosm volumes}

Oxygen minimum zones are a significant feature of EBUS and play an important role for ecological and biogeochemical processes in the Humboldt system (Breitburg et al., 2018; Thiel et al., 2007). They reach very close to the surface $(<10 \mathrm{~m})$ in the near-coast region of Peru (Graco et al., 2017); therefore the mesocosms naturally contained water with low $\mathrm{O}_{2}$ concentrations below $\sim 10 \mathrm{~m}$ (see "Results"). Conserving this oxygen-depleted bottom layer within the mesocosms required artificial water column stratification because heat exchange with the surrounding Pacific water would have destroyed this feature (see Bach et al., 2016a, for a description of the convective-mixing phenomenon in mesocosms). Therefore, we injected $69 \mathrm{~L}$ of a concentrated $\mathrm{NaCl}$ brine solution evenly into the bottom layers of the mesocosms on Day 13 by carefully moving a custom-made distribution device (Riebesell et al., 2013) up and down between 10 and $17 \mathrm{~m}$. The procedure was repeated on Day 33 with $46 \mathrm{~L} \mathrm{NaCl}$ brine solution added between 12.5 and $17 \mathrm{~m}$ after turbulent mixing between days 13 and 33 continuously blurred the artificial halocline. The brine additions increased bottom-water salinity by about 1 during both additions (Fig. 3b).

At the end of the experiment (Day 50, after the last sampling), we performed a third $\mathrm{NaCl}$ brine addition to determine the volume of each mesocosm. For volume determination, we first homogenized the enclosed water columns by pumping compressed air into the bottom layer for $5 \mathrm{~min}$, thereby fully mixing the water masses. This was validated by salinity profiling with subsequent CTD casts (see Sect. 2.4 for CTD specifications). Next, we added $52 \mathrm{~kg}$ of a $\mathrm{NaCl}$ brine evenly to the entire water column as described above, followed by a second airlift mixing and second set of CTD casts. Since we precisely knew the added amount of $\mathrm{NaCl}$, we were able to determine the volume of the mesocosms at Day 50 from the measured salinity increase as described by Czerny et al. (2013). The mesocosm volumes before Day 50 were calculated for each sampling day based on the volume that was withdrawn during sampling (Sect. 2.5) and exchanged during the OMZ water addition (Sect. 2.2). Rainfall did not occur during the study, and evaporation was negligible $\left(\sim 1 \mathrm{Ld}^{-1}\right)$ as determined by monitoring salinity over time (Sect. 2.5). These two factors were therefore not considered for the volume calculations.

The $\mathrm{NaCl}$ solution used to establish haloclines was prepared in Germany by dissolving $300 \mathrm{~kg}$ of food-grade $\mathrm{NaCl}$ in $1000 \mathrm{~L}$ deionized water (Milli-Q, Millipore; Czerny et al., 2013). The brine was purified thereafter with ion exchange resin (Lewatit ${ }^{\mathrm{TM}}$ MonoPlus TP $260^{\circledR}$, Lanxess, Germany) to minimize potential contaminations with trace metals (Czerny et al., 2013). The purified brine was collected in an acidcleaned polyethylene canister $(1000 \mathrm{~L})$, sealed, and transported from Germany to Peru where it was used $\sim 5$ months later. The brine solution for the volume determination at the end of the experiment was produced on-site using table salt purchased locally.

\subsection{Additions of organisms}

Some of the research questions of this campaign involved endemic organisms that were initially not enclosed in the mesocosms, at least not in sufficient quantities for meaningful quantitative analyses. These were scallop larvae (Argopecten purpuratus, Peruvian scallop) and eggs of the fish Paralichthys adspersus (fine flounder). Both scallop larvae and fish eggs were introduced by lowering a container of the organisms to the water surface and carefully releasing them into the mesocosms. Scallop larvae were added on Day 14 in concentrations of $\sim 10000$ individuals $\mathrm{m}^{-3}$. Fish eggs were added on Day 31 in concentrations of $\sim 90$ individuals $\mathrm{m}^{-3}$. However, few scallop larvae and no fish larvae were found in the mesocosms after the release so that their influence on the plankton community should have been small and will only be considered in specific zooplankton papers in this special issue.

\subsection{Sampling and CTD casts}

Sampling and CTD casts were undertaken from small boats that departed from La Punta harbor (Callao; Fig. 1) around 06:30 local time and reached the study site around 07:00. The sampling scheme was consistent throughout the study. 
(a)

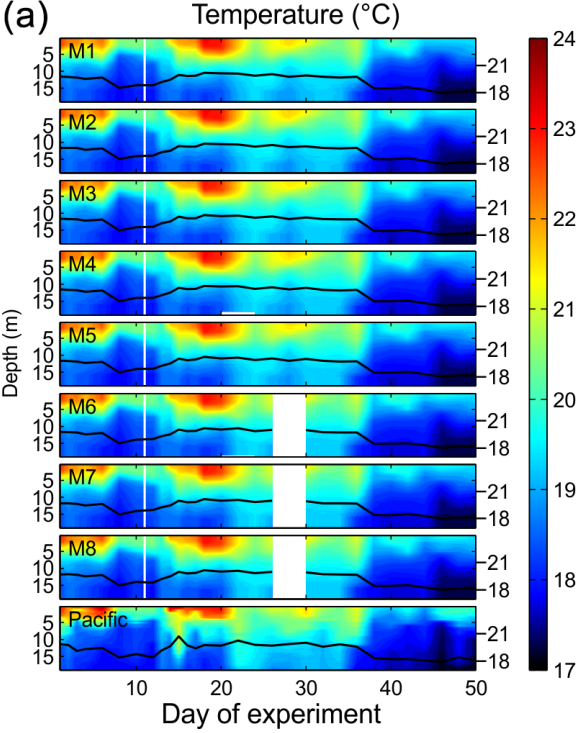

(b)

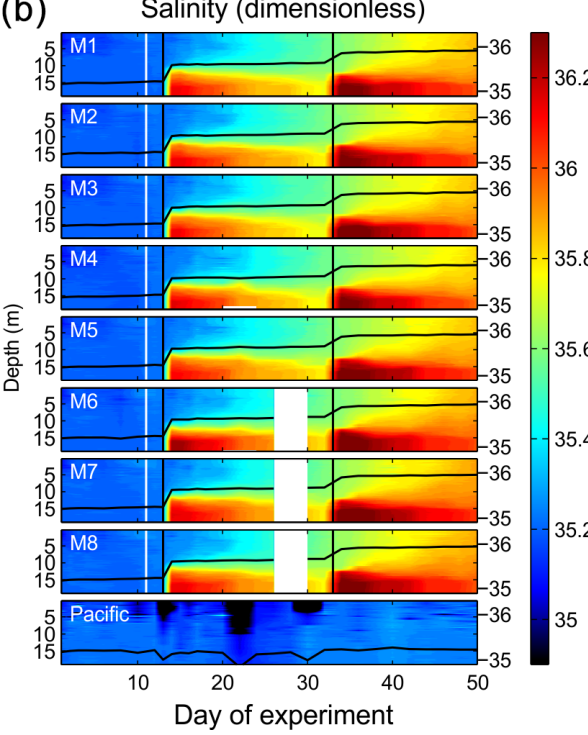

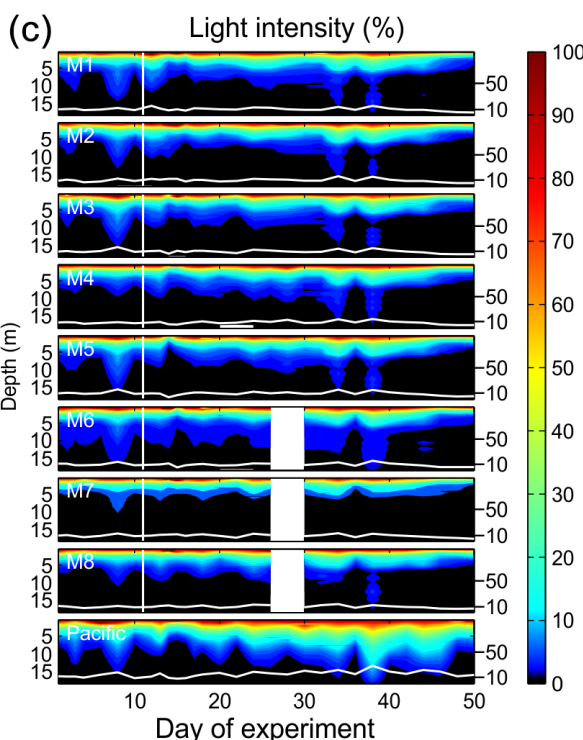

(d)

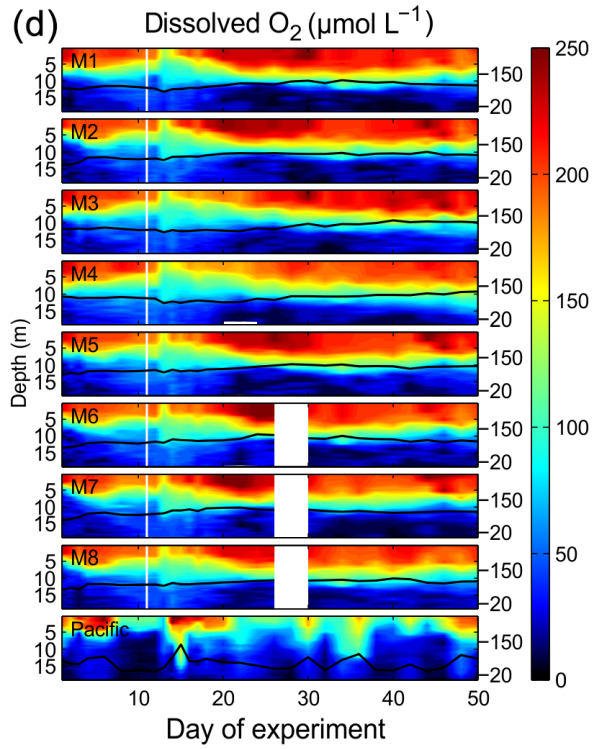

Figure 3. Physical and chemical conditions in the enclosed water columns of mesocosms M1-M8 and the Pacific water at the mesocosm mooring site determined with CTD casts. The black $(\mathbf{a}, \mathbf{b}, \mathbf{d})$ or white (c) lines on top of the contours show the depth-integrated water column average with the corresponding additional $y$ axes on the right side. The vertical white lines indicate the time of OMZ water additions to the mesocosms. The lack of data on Day 28 in M6, M7, and M8 was due to problems with power supply. (a) Temperature in degrees Celsius. (b) Salinity (dimensionless). The vertical black lines mark the $\mathrm{NaCl}$ brine additions. (c) Light intensity (photosynthetic active radiation) normalized to surface irradiance in the upper $0.3 \mathrm{~m}$. (d) Dissolved- $\mathrm{O}_{2}$ concentrations.

The sediment traps were sampled first to avoid resuspension of the settled material during deployment of our watersampling gear. Water column sampling and CTD casts followed $\sim 10 \mathrm{~min}$ after sediment trap sampling. The sediment trap sampling lasted for $1 \mathrm{~h}$, while the CTD casts lasted for $2 \mathrm{~h}$, after which the sediment and CTD teams went back to the harbor. Water-column-sampling teams remained at the mesocosms for $2-6 \mathrm{~h}$ and arrived back in the harbor mostly between 11:00 and 14:00. Care was taken to sample mesocosms and surrounding Pacific waters (which were sampled next to the mesocosms during every sampling) in random order. Sampling containers were stored in cool boxes until further processing on land. Details of the individual sampling procedures are described in the following where necessary.

Sinking detritus was collected in the sediment traps at the bottom of each mesocosm and recovered every second day (Fig. 2) using a vacuum-pumping system described by Boxhammer et al. (2016). Briefly, a silicon hose $(10 \mathrm{~mm}$ inner diameter) attached to the collector at the very bottom of the traps led to the surface where it was fixed above sea level 
at one of the pylons of the flotation frame and closed with a clip (Fig. 1a). The sampling crew attached a $5 \mathrm{~L}$ glass bottle (Schott Duran) to the upper end of the hose and generated a vacuum $(\sim 300$ mbar $)$ within the bottle using a manual air pump so that the sediment material was sucked through the hose and collected in the $5 \mathrm{~L}$ bottle after the clip was loosened.

Suspended and dissolved substances investigated in this study comprised particulate organic carbon (POC) and particulate organic nitrogen (PON), total particulate carbon (TPC) and total particulate phosphorus (TPP), biogenic silica (BSi), phytoplankton pigments, nitrate $\left(\mathrm{NO}_{3}^{-}\right)$, nitrite $\left(\mathrm{NO}_{2}^{-}\right)$, phosphate $\left(\mathrm{PO}_{4}^{3-}\right)$, silicic acid $\left(\mathrm{Si}(\mathrm{OH})_{4}\right)$, ammonium $\left(\mathrm{NH}_{4}^{+}\right)$, and dissolved organic nitrogen (DON) and dissolved organic phosphorus (DOP). Suspended and dissolved substances were collected with $5 \mathrm{~L}$ integrating water samplers (IWSs; Hydro-Bios, Kiel) which are equipped with pressure sensors to collect water evenly within a desired depth range. We sampled two separate depth ranges (surface and bottom water). The reason for this separation was that we wanted to have specific samples for the low- $\mathrm{O}_{2}$ bottom water. These depth ranges were $0-5$ and 5-17 $\mathrm{m}$ from Day 1 to $2,0-10$ and $10-17 \mathrm{~m}$ from Day 3 to 28 , and $0-12.5$ and $12.5-$ $17 \mathrm{~m}$ from Day 29 to 50 (Fig. 2). The reason for the changing separation was that the oxycline was changing slightly during the experiment. However, for the present paper we only show IWS-collected data averaged over the entire water column $(0-17 \mathrm{~m})$ as this was more appropriate for the data evaluation within this particular paper (for example, POC on Day $\left.30=\left(12.5 \times \mathrm{POC}_{0-12.5 \mathrm{~m}}+4.5 \times \mathrm{POC}_{12.5-17 \mathrm{~m}}\right) / 17\right)$. Surface and bottom water for POC, PON, TPC, TPP, BSi, and phytoplankton pigments were carefully transferred from the IWS into separate $10 \mathrm{~L}$ polyethylene carboys. Samples for inorganic and organic nutrients were transferred into $250 \mathrm{~mL}$ polypropylene and acid-cleaned glass bottles, respectively. All containers were rinsed with Milli-Q water in the laboratory and prerinsed with sample water immediately before transferring the actual samples. Trace-metal clean sampling was restricted to three occasions (days 3, 17, and 48) due to logistical constraints. Therefore, acid-cleaned plastic tubing was fitted to a Teflon pump, submerged directly into the mesocosms, and used to pump water from surface and bottom waters (depths as per macronutrients) for the collection of water under trace-metal clean conditions.

Depth profiles of salinity, temperature, $\mathrm{O}_{2}$ concentration, photosynthetically active radiation (PAR), and chlorophyll $a$ (chl $a$ ) fluorescence were measured with vertical casts of a CTD60M sensor system (Sea \& Sun Technology) on each sampling day (Fig. 2). Details of the salinity, temperature, PAR, and fluorescence sensors were described by Schulz and Riebesell (2013). The fast oxygen optical sensor measured dissolved- $\mathrm{O}_{2}$ concentrations at $620 \mathrm{~nm}$ excitation and $760 \mathrm{~nm}$ detection wavelengths. The sensor is equipped with a separate temperature sensor for internal calculation and lin- earization. It has a response time of $2 \mathrm{~s}$ and was calibrated with $\mathrm{O}_{2}$-saturated and $\mathrm{O}_{2}$-depleted seawater. Absolute concentrations at discrete depths were compared with Winkler $\mathrm{O}_{2}$ titration measurements. These were taken in triplicate with a Niskin sampler on Day 40 at a $15 \mathrm{~m}$ water depth in M8 and on Day 42 at $1 \mathrm{~m}$ in M3. Samples were filled into glass bottles allowing significant overflow and closed airtight without headspace. All samples were measured on the same day with a micro Winkler titration device as described by Arístegui and Harrison (2002). We only used CTD data from the downward cast since the instrument has no pump to supply the sensors mounted at the bottom with a constant water flow. A 3 min latency period with the CTD hanging at $\sim 2 \mathrm{~m}$ before the casts ensured sensor acclimation to the enclosed water masses and the Pacific water.

\subsection{Sample processing, measurements, and data analyses}

All samples were further processed in laboratories in Club Náutico Del Centro Naval and the Instituto del Mar del Perú (IMARPE). Sediment trap samples were processed directly after the sampling boats returned to the harbor. First, the sample weight was determined gravimetrically. Then the $5 \mathrm{~L}$ bottles were carefully rotated to resuspend the material and homogenous subsamples collected for additional analyses (e.g., particle sinking velocity) described in companion papers of this special issue. The remaining sample (always $>88 \%)$ was enriched with $3 \mathrm{M} \mathrm{FeCl}_{3}$ and $3 \mathrm{M} \mathrm{NaOH}(0.12$ and $0.39 \mu \mathrm{L}$, respectively, per gram of sample) to adjust the $\mathrm{pH}$ to 8.1. The $\mathrm{FeCl}_{3}$ addition initiated flocculation and coagulation with subsequent sedimentation of particles within the $5 \mathrm{~L}$ bottle (Boxhammer et al., 2016). After $1 \mathrm{~h}$, most of the supernatant above the settled sample was carefully removed, and the remaining sample was centrifuged in two steps: (1) for $10 \mathrm{~min}$ at $\sim 5200 \mathrm{~g}$ in a $800 \mathrm{~mL}$ beaker using a 6-16KS centrifuge (Sigma) and (2) for $10 \mathrm{~min}$ at $\sim 5000 \mathrm{~g}$ in a $110 \mathrm{~mL}$ beaker using a $3 \mathrm{~K} 12$ centrifuge (Sigma). The supernatants were removed after both steps, and the remaining pellet was frozen at $-20^{\circ} \mathrm{C}$. The remaining water was removed by freeze-drying the sample. The dry pellet was ground in a ball mill to generate a homogenous powder (Boxhammer et al., 2016).

Subsamples of the powder were used to determine TPC and PON content with an elemental analyzer following Sharp (1974). POC subsamples were treated identically but put into silver instead of tin capsules, acidified for $1 \mathrm{~h}$ with $1 \mathrm{M} \mathrm{HCl}$ to remove any particulate inorganic carbon, and dried at $50{ }^{\circ} \mathrm{C}$ overnight. TPP subsamples were autoclaved for $30 \mathrm{~min}$ in $100 \mathrm{~mL}$ Schott Duran glass bottles using an oxidizing decomposition solution (Merck, catalogue no. 112936) to convert organic $\mathrm{P}$ to orthophosphate. $\mathrm{P}$ concentrations were determined spectrophotometrically following Hansen and Koroleff (1999). BSi subsamples were leached by alkaline pulping with $0.1 \mathrm{M} \mathrm{NaOH}$ at $85^{\circ} \mathrm{C}$ in 
$60 \mathrm{~mL}$ Nalgene polypropylene bottles. After $135 \mathrm{~min}$ the leaching process was terminated with $0.05 \mathrm{M} \mathrm{H}_{2} \mathrm{SO}_{4}$, and the dissolved-Si concentration was measured spectrophotometrically following Hansen and Koroleff (1999). POC, PON, TPP, and BSi concentrations of the weighed subsamples were scaled to represent the total sample weight so that we ultimately determined the total element flux to the sediment traps.

Suspended TPC, POC, PON, TPP, BSi, and pigment concentrations sampled with the IWS in the water columns were immediately transported to the laboratory and filtered onto either precombusted $\left(450^{\circ} \mathrm{C}, 6 \mathrm{~h}\right)$ glass-fiber filters $(\mathrm{GF} / \mathrm{F}$, $0.7 \mu \mathrm{m}$ nominal pore size, Whatman; POC, PON, TPP, pigments) or cellulose acetate filters $(0.65 \mu \mathrm{m}$ pore size, Whatman; BSi), applying a gentle vacuum of 200 mbar. The filtration volumes were generally between 100 and $500 \mathrm{~mL}$ depending on the variable amount of particulate material present in the water columns. Samples were stored in precombusted $\left(450^{\circ} \mathrm{C}, 6 \mathrm{~h}\right)$ glass petri dishes (TPC, POC, PON), in separate $100 \mathrm{~mL}$ Schott Duran glass bottles (TPP), in $60 \mathrm{~mL}$ Nalgene polypropylene bottles $(\mathrm{BSi})$, or in cryo vials (pigments). After filtrations, $\mathrm{POC}$ and $\mathrm{PON}$ filters were acidified with $1 \mathrm{~mL}$ of $1 \mathrm{M} \mathrm{HCl}$, dried overnight at $60^{\circ} \mathrm{C}$, put into tin capsules, and stored in a desiccator until analysis in Germany at GEOMAR following Sharp (1974). TPC samples were treated identically, except for the acidification step, and they were dried in a separate oven to avoid contact with any acid fume. TPP and BSi filters in the glass and polypropylene bottles, respectively, were stored at $-20^{\circ} \mathrm{C}$ until enough samples had accumulated for one measurement run. TPP and BSi measurements of suspended material were completed in the laboratory in Peru so that no sample transport was necessary. P and Si were extracted within the bottles and measured thereafter as described for the sediment powder.

Pigment samples were flash-frozen in liquid nitrogen directly after filtration and stored at $-80^{\circ} \mathrm{C}$. The frozen pigment samples were transported to Germany on dry ice within $3 \mathrm{~d}$ by World Courier. In Germany, samples were stored at $-80^{\circ} \mathrm{C}$ until extraction as described by Paul et al. (2015). Concentrations of extracted pigments were measured by means of reverse-phase high-performance liquid chromatography (HPLC; Barlow et al., 1997) calibrated with commercial standards. The contribution of distinct phytoplankton taxa to the total chl $a$ concentration was calculated with CHEMTAX which classifies phytoplankton taxa based upon taxon-specific pigment ratios (Mackey et al., 1996). The dataset was binned into two CHEMTAX runs: one for the surface layer and one for the deeper layer (Sect. 2.4) As input pigment ratios we used the values for the Peruvian upwelling system determined by DiTullio et al. (2005) as described by Meyer et al. (2017).

Samples for inorganic nutrients were filtered $(0.45 \mu \mathrm{m}$ filter, Sterivex, Merck) immediately after they had arrived in the laboratories at IMARPE. The subsequent analysis was carried out using an autosampler (XY2 autosampler, SEAL Analytical) and a continuous flow analyzer (QuAAtro AutoAnalyzer, SEAL Analytical) connected to a fluorescence detector (FP-2020, JASCO). $\mathrm{PO}_{4}^{3-}$ and $\mathrm{Si}(\mathrm{OH})_{4}$ were analyzed colorimetrically following the procedures by Murphy and Riley (1962) and Mullin and Riley (1955), respectively. $\mathrm{NO}_{3}^{-}$and $\mathrm{NO}_{2}^{-}$were quantified through the formation of a pink azo dye as established by Morris and Riley (1963). All colorimetric methods were corrected with the refractive index method developed by Coverly et al. (2012). Ammonium concentrations were determined fluorometrically (Kérouel and Aminot, 1997). The limit of detection (LOD) was calculated from blank measurements as blank +3 times the standard deviation of the blank (Thompson and Wood, 1995) over the course of the experiment $\left(\mathrm{LOD} \quad \mathrm{NH}_{4}^{+}=0.063 \mu \mathrm{mol} \mathrm{L}-1, \quad \mathrm{NO}_{2}^{-}=0.054 \mu \mathrm{mol} \mathrm{L}^{-1}\right.$, $\mathrm{NO}_{3}^{-}=0.123 \mu \mathrm{mol} \mathrm{L}{ }^{-1}, \quad \mathrm{PO}_{4}^{3-}=0.033 \mu \mathrm{mol} \mathrm{L}{ }^{-1}$, $\left.\mathrm{Si}(\mathrm{OH})_{4}=0.336 \mu \mathrm{mol} \mathrm{L}^{-1}\right)$. The precision of the measurements was estimated from the average standard deviation between replicates over the course of the experiment $\left(\mathrm{NH}_{4}^{+}=0.027 \mu \mathrm{mol} \mathrm{L}{ }^{-1}, \mathrm{NO}_{2}^{-}=0.014 \mu \mathrm{mol} \mathrm{L}^{-1}\right.$, $\mathrm{NO}_{3}^{-}=0.033 \mu \mathrm{mol} \mathrm{L}{ }^{-1}, \quad \mathrm{PO}_{4}^{3-}=0.016 \mu \mathrm{mol} \mathrm{L}^{-1}$, $\left.\mathrm{Si}(\mathrm{OH})_{4}=0.016 \mu \mathrm{mol} \mathrm{L}^{-1}\right)$. The accuracy was monitored by including certified reference material (CRM; lot BW, KANSO) during measurements. The accuracy was mostly within $C R M \pm 5 \%$ and was $\pm 10 \%$ in the worst case.

After transportation to the laboratory, TDN and TDP samples were gently filtered through precombusted $\left(5 \mathrm{~h}, 450^{\circ} \mathrm{C}\right)$ glass-fiber filters (GF/F, $0.7 \mu \mathrm{m}$ pore size Whatman) using a diaphragm metering pump (KNF Stepdos, continuous flow of $100 \mathrm{~mL} \mathrm{~min}^{-1}$ ). The filtrate was collected in $50 \mathrm{~mL}$ acidcleaned HDPE bottles and immediately frozen at $-20^{\circ} \mathrm{C}$ until further analysis. For the determination of organic nutrient concentrations, filtered samples were thawed at room temperature over a period of $24 \mathrm{~h}$ and divided in half. One-half was used to determine inorganic nutrient concentrations as described above. The other half was used to determine TDN and TDP concentrations. In order to liberate inorganic nutrients and oxidize nutrients, an oxidizing reagent (Oxisolv, Merck) was added to samples, and these were subsequently autoclaved for $30 \mathrm{~min}$ and analyzed spectrophotometrically (QuAAtro, Seal Analytical). DON concentrations were calculated by subtracting inorganic nitrogen $\left(\mathrm{NO}_{3}^{-}\right.$and $\left.\mathrm{NO}_{2}^{-}\right)$ from total dissolved nitrogen (TDN). DOP was calculated as the difference between TDP and $\mathrm{PO}_{4}^{3-}$.

Water samples for trace-metal analysis were filtered $(0.20 \mu \mathrm{m}$, Millipore) into $125 \mathrm{~mL}$ low-density polyethylene (LDPE) bottles which were precleaned sequentially with detergent (1 week), $1.2 \mathrm{M} \mathrm{HCl}$ (1 week), and $1.2 \mathrm{M} \mathrm{HNO}_{3}$ (1 week), with deionized water rinses between each stage, and then stored in LDPE bags until required. Syringes and filters were precleaned with $0.1 \mathrm{M} \mathrm{HCl}$. Samples were acidified with $180 \mu \mathrm{L} \mathrm{HCl}(\mathrm{UpA}$, Romil) in a laminar flow hood upon return to the laboratory and allowed to stand $>12$ months 
prior to analysis. Dissolved-trace-metal concentrations were determined following offline preconcentration on a seaFAST system via inductively coupled plasma mass spectrometry, exactly as per Rapp et al. (2017).

\section{Results}

\subsection{Physical and chemical conditions in the water columns}

The water columns enclosed at the beginning of the study were thermally stratified with a thermocline roughly at $5 \mathrm{~m}$ (Fig. 3). Surface temperatures were unusually high (up to $25^{\circ} \mathrm{C}$ ) during most of the first $40 \mathrm{~d}$ due to a rare coastal $\mathrm{El}$ Niño phase in austral summer 2017 (Garreaud, 2018). The coastal El Niño ceased towards the end of the experiment (i.e., beginning of April, Day 38), and surface temperatures went back to more typical values for this time of the year $\left(<20^{\circ} \mathrm{C}\right)$. When averaged over the entire water column in all mesocosms, temperatures ranged between 18.4 and $20.2^{\circ} \mathrm{C}$ from days 1 to 38 and between 17.9 and $18.6^{\circ} \mathrm{C}$ thereafter. Temperature profiles were very similar inside and outside the mesocosms due to rapid heat exchange (Fig. 3).

The salinity in the mesocosms was initially between 35.16 and 35.19, with little variation over the $19 \mathrm{~m}$ water column (Fig. 3). $\mathrm{NaCl}$ brine additions to below $10 \mathrm{~m}$ on Day 13 and below $12.5 \mathrm{~m}$ on Day 33 (Sect. 2.3) increased the salinity in the bottom layer by $\sim 0.7$ and $\sim 0.5$, respectively. The salinity stratification stabilized the water column, but sampling operations during the experiment gradually mixed bottom water into the surface layer so that the salinity above $10 \mathrm{~m}$ also increased. When averaged over the entire water column, salinities were 35.16-35.24 until Day 13, 35.57-35.67 between days 13 and 33, and 35.84-35.95 thereafter. The salinity in the Pacific water outside the mesocosms was relatively stable at around an average of 35.17 with three fresher periods in the surface layer due to river water inflow (Fig. 3). The salinity addition for mesocosm volume determination at the end of the experiment revealed that the mesocosms contained volumes of between 52.5 and $55.8 \mathrm{~m}^{3}$ (Table 1).

The highest photon flux density measured at the surface inside the mesocosms ( $\sim 0.1 \mathrm{~m}$ depth) around noontime were $\sim 500-600 \mu \mathrm{mol} \mathrm{m}^{-2} \mathrm{~s}^{-1}$. PAR was on average about $35 \%$ lower inside the mesocosms than outside due to shading by the flotation frame and the bag. Figure 3 shows light profiles relative to surface values (instead of absolute values) because CTD casts were conducted at slightly different times of day and would therefore not be comparable on an absolute scale. Light attenuation with depth was pronounced due to the high particle concentrations in the water. Inside the mesocosms, $10 \%$ and $1 \%$ incident light levels were generally shallower than 5 and $10 \mathrm{~m}$. Outside, they were at slightly greater depths (Fig. 3).
Dissolved- $\mathrm{O}_{2}$ concentrations $\left(\mathrm{dO}_{2}\right)$ inside and outside the mesocosms decreased from $>200 \mu \mathrm{mol} \mathrm{L}^{-1}$ at the surface to $<50 \mu \mathrm{mol} \mathrm{L}{ }^{-1}$ at depth (Fig. 3). The oxycline inside the mesocosms was between 5 and $15 \mathrm{~m}$. Oxycline depths were more variable outside the mesocosms where low- $\mathrm{dO}_{2}$ events occurred more frequently in the upper water column. OMZ waters collected from nearby stations 1 and 3 (Fig. 1) were added to the mesocosms on days 11 and 12. The water column mixing as a consequence of the OMZ water addition led to the decrease in $\mathrm{dO}_{2}$ in the surface layer and an increase in $\mathrm{dO}_{2}$ in the lower depths of the mesocosms. After Day 12, the salinity stratification stabilized the vertical $\mathrm{dO}_{2}$ gradient which remained relatively constant until the end of the experiment. Optode measurements had an offset of $+13 \mu \mathrm{mol} \mathrm{L}-1$ in the bottom layer $(15 \mathrm{~m})$ and $-16 \mu \mathrm{mol} \mathrm{L}^{-1}$ in the surface $(1 \mathrm{~m})$ relative to the Winkler measurements. Thus, there are inaccuracies of $\pm 10-20 \mu \mathrm{mol} \mathrm{L}^{-1}$. These inaccuracies were most likely due to limitations associated with the response time of the sensor and therefore nonrandom but led to carryover along gradients. Nevertheless, the general trend observed in the vertical $\mathrm{dO}_{2}$ gradient as well as changes over time should be correctly represented in the present dataset.

\subsection{Inorganic and organic nutrients}

$\mathrm{NO}_{3}^{-}+\mathrm{NO}_{2}^{-}$concentrations $\left(\mathrm{NO}_{x}^{-}\right)$in the mesocosms were initially between 5.6 and $7.6 \mu \mathrm{mol} \mathrm{L}{ }^{-1}$ and decreased in all mesocosms to $1.1-5.5 \mu \mathrm{mol} \mathrm{L}-1$ on days 11 and 12 (Fig. $4 \mathrm{a}$; Table 1). After the $\mathrm{OMZ}$ water addition, $\mathrm{NO}_{x}^{-}$increased slightly in M2, M3, M6, and M7 (Fig. 4a, blue symbols) as the OMZ source water from station 3 contained $4 \mu \mathrm{mol} \mathrm{L}^{-1}$ of $\mathrm{NO}_{x}^{-} . \mathrm{M} 1, \mathrm{M} 4, \mathrm{M} 5$, and $\mathrm{M} 8$ received OMZ water from station 1 with $0.3 \mu \mathrm{mol} \mathrm{L}^{-1}$, and $\mathrm{NO}_{x}^{-}$was therefore lower after the OMZ water addition (Fig. 4a, red symbols). The difference in $\mathrm{NO}_{x}^{-}$between the two OMZ treatments was relatively small $\left(2.2 \mu \mathrm{mol} \mathrm{L}^{-1}\right)$ but significant $(p<0.05$; Table 1$)$. After the $\mathrm{OMZ}$ water addition, $\mathrm{NO}_{x}^{-}$declined and reached the detection limit (i.e., $0.2 \mu \mathrm{mol} \mathrm{L}-1$ for $\mathrm{NO}_{3}^{-}$) between days 18 (M7) and 36 (M4). $\mathrm{NO}_{x}^{-}$was between 2.7 and $19.2 \mu \mathrm{mol} \mathrm{L}^{-1}$ in the Pacific water at the deployment site and particularly high during the second half of the experiment (Fig. 4a).

$\mathrm{PO}_{4}^{3-}$ concentrations in the mesocosms were initially between 1.4 and $2 \mu \mathrm{mol} \mathrm{L}{ }^{-1}$ and converged to $\sim 1.6 \mu \mathrm{mol} \mathrm{L}-1$ in all mesocosms $5 \mathrm{~d}$ after the start of the experiment (Fig. 4b). The OMZ water contained $2.5 \mu \mathrm{mol} \mathrm{L}^{-1}$ of $\mathrm{PO}_{4}^{3-}$ at both stations, so its addition increased the $\mathrm{PO}_{4}^{3-}$ concentrations in the mesocosms to $\sim 2 \mu \mathrm{mol} \mathrm{L}^{-1}$ (Table 1). Afterwards, $\mathrm{PO}_{4}^{3-}$ decreased in all mesocosms but generally more in M2, M3, M6, and M7 (blue symbols in the figures) where slightly more $\mathrm{NO}_{x}^{-}$was added through the $\mathrm{OMZ}$ water addition. $\mathrm{PO}_{4}^{3-}$ decreased during the second half of the experiment and was between 1.3 and $1.8 \mu \mathrm{mol} \mathrm{L}^{-1}$ at the end. $\mathrm{PO}_{4}^{3-}$ was between 1.5 and $3.1 \mu \mathrm{mol} \mathrm{L}{ }^{-1}$ in the Pacific water and generally higher than in the mesocosms (Fig. 4b). 


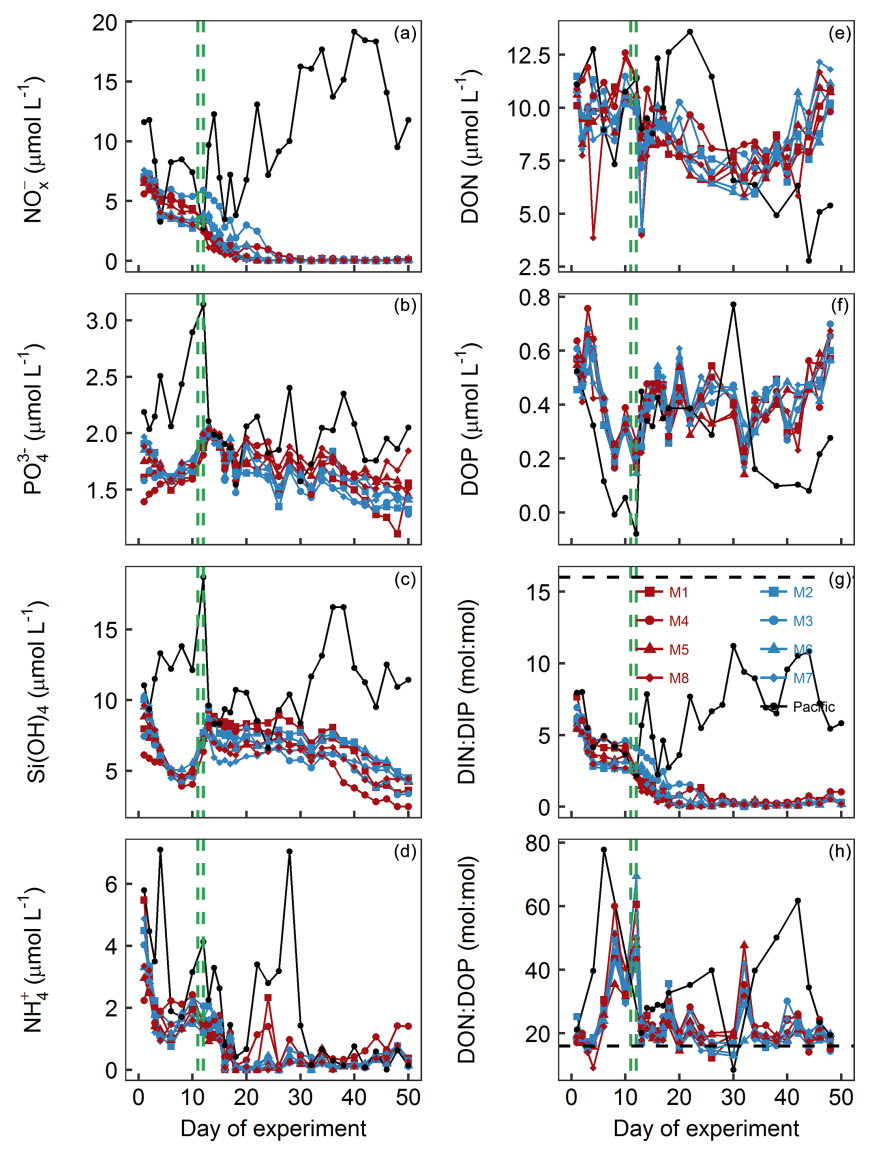

Figure 4. Dissolved-inorganic-nutrient and dissolved-organicnutrient concentrations and stoichiometries integrated over the 0$17 \mathrm{~m}$ depth range. The horizontal dashed black line in panel (g) displays the Redfield ratio of DIN : $\mathrm{DIP}=16$. The green lines mark the days of $\mathrm{OMZ}$ water additions. (a) $\mathrm{NO}_{3}^{-}+\mathrm{NO}_{2}^{-}$. (b) $\mathrm{PO}_{4}^{3-}$. (c) $\mathrm{Si}(\mathrm{OH})_{4} \cdot$ (d) $\mathrm{NH}_{4}^{+}$. (e) DON. (f) DOP. (g) DIN : DIP, i.e., $\left(\mathrm{NO}_{x}^{-}+\mathrm{NH}_{4}^{+}\right) / \mathrm{PO}_{4}^{3-}$. (h) DON/DOP.

$\mathrm{Si}(\mathrm{OH})_{4}$ concentrations in the mesocosms were initially between 6.1 and $10.3 \mathrm{mmol} \mathrm{L}^{-1}$ and decreased in all mesocosms until Day 6 to values of between 4.5 and $5.1 \mu \mathrm{mol} \mathrm{L}{ }^{-1}$ (Fig. 4c). The OMZ water at station 1 and 3 contained 17.4 and $19.6 \mu \mathrm{mol} \mathrm{L}^{-1}$ of $\mathrm{Si}(\mathrm{OH})_{4}$, respectively, so their additions increased the concentrations to $7.5-9.5 \mu \mathrm{mol} \mathrm{L}^{-1}$ inside the mesocosms (Table 1). Concentrations remained quite stable at this level until Day 26, after which they decreased in all mesocosms to $2.5-4.5 \mu \mathrm{mol} \mathrm{L}^{-1}$ at the end of the study. $\mathrm{Si}(\mathrm{OH})_{4}$ was between 6.6 and $18.7 \mu \mathrm{mol} \mathrm{L}^{-1}$ in the Pacific water and generally higher than inside the mesocosms, except for a few days (Fig. 4c).

$\mathrm{NH}_{4}^{+}$concentrations were initially between 2.2 and $5.5 \mu \mathrm{mol} \mathrm{L}{ }^{-1}$ and decreased to values $<2 \mu \mathrm{mol} \mathrm{L}{ }^{-1}$ on days 2-3 (Fig. 4d). $\mathrm{NH}_{4}^{+}$increased thereafter (except for M8) to reach $1.5-2.4 \mu \mathrm{mol} \mathrm{L}^{-1}$ on Day 10. After the OMZ addition, $\mathrm{NH}_{4}^{+}$concentrations $\left(0.6 \mu \mathrm{mol} \mathrm{L}^{-1}\right)$ were slightly but significantly higher in M2, M3, M6, and M7, which received $\mathrm{OMZ}$ water from station 3 (blue symbols, Table 1). $\mathrm{NH}_{4}^{+}$ concentrations decreased to values close to or below the limit of detection until Day 18. Concentrations remained at a low level but increased slightly by the end of the experiment to values of between 0.1 and $1.4 \mu \mathrm{mol} \mathrm{L}{ }^{-1} . \mathrm{NH}_{4}^{+}$concentrations ranged between the limit of detection and $7.1 \mu \mathrm{mol} \mathrm{L}^{-1}$ in the Pacific water and coincidently showed a similar temporal pattern to that in the mesocosms except for the time between Day 10 and Day 20 when the concentrations were considerably higher (Fig. 4d).

DON concentrations in the mesocosms were initially between 10.1 and $11.5 \mu \mathrm{mol} \mathrm{L}{ }^{-1}$ and remained roughly within this range until the OMZ water addition. Afterwards, DON decreased to 6-7.9 $\mu \mathrm{mol} \mathrm{L}{ }^{-1}$ on Day 30 but then increased almost exponentially until the end of the experiment (Fig. 4e). DON in the Pacific water was within a similar range to that in the mesocosms until the OMZ water addition but shifted to higher concentrations $\left(10-13.6 \mu \mathrm{mol} \mathrm{L}^{-1}\right)$ from Day 16 to 22 , followed by an abrupt decrease to $2.8-11.5$ from Day 24 until the end of the experiment.

DOP concentrations in the mesocosms were initially between 0.45 and $0.63 \mu \mathrm{mol} \mathrm{L}{ }^{-1}$ but declined sharply to $0.16-$ $0.25 \mu \mathrm{mol} \mathrm{L}{ }^{-1}$ on Day 8. DOP increased after the OMZ water addition to $0.22-0.38 \mu \mathrm{mol} \mathrm{L}^{-1}$ (Table 1) and remained roughly at this level until Day 40, after which it began to increase to $0.56-0.7 \mu \mathrm{mol} \mathrm{L}{ }^{-1}$ towards the end of the experiment. There were several day-to-day fluctuations consistent among the mesocosms, and we cannot exclude the possibility that these are due to measurement inaccuracies (Fig. 4f). DOP in the Pacific water was initially similar to the mesocosms but decreased in the first week of the study to reach undetectable levels on Day 8. It increased, as in the mesocosms, on Day 13 and remained at $0.29-0.45 \mu \mathrm{mol} \mathrm{L}^{-1}$ until Day 32. After a short peak of $0.77 \mu \mathrm{mol} \mathrm{L}^{-1}$ on Day 34, DOP declined to $0.08-0.28 \mu \mathrm{mol} \mathrm{L}{ }^{-1}$ until the end of the experiment.

DIN : DIP (i.e., $\left(\mathrm{NO}_{x}^{-}+\mathrm{NH}_{4}^{+}\right)$: $\mathrm{PO}_{4}^{3-}$ ) in the mesocosms was constantly below the Redfield ratio (i.e., 16), and its development largely resembled that of $\mathrm{NO}_{x}^{-}$as the predominant nitrogen source (compare Fig. 4a and g). It was initially 5.47.7. After the OMZ water addition, DIN : DIP was significantly different between the two treatments (Table 1) because there was more DIN in the OMZ water added to M2, M3, M6, and M7 (blue symbols, Table 1). DIN : DIP decreased to 0.04-0.37 until Day 26 and remained at these low levels until the end of the experiment. DIN : DIP in the Pacific water was similar to the mesocosms until Day 13 but considerably higher (2.2-11.2) thereafter (Fig. 4g).

DON : DOP in the mesocosms was initially close to the Redfield ratio (i.e., 16) but increased to 29.2-40.4 until the OMZ water addition. Afterwards, DON : DOP declined to values slightly above the Redfield ratio and remained at this level until the end of the experiment. The occasional fluctuations towards higher values reflect the fluctuations in DOP 
(compare Fig. 4f and h). DON : DOP in the Pacific water was mostly above the Redfield ratio and generally higher than in the mesocosms. It was initially 21.1 , increased to 77.6 on Day 6, and then rapidly declined to initial values. Afterwards, DON : DOP increased from 21.1 to 61.8 on Day 42 (with one exceptionally low value on Day 30) but then decreased to 19.5 at the end of the experiment (Fig. 4h).

Dissolved-iron (dissolved-Fe) concentrations were nonlimiting in all mesocosms with concentrations ranging from 3.1 to $17.8 \mathrm{nM}$ (Table S1 in the Supplement; Bruland et al., 2005). The resolution of trace-metal clean sampling was insufficient for discussing the temporal trends in detail, although surface concentrations appeared to be lower on Day 48 (3.1-9.5 nM) than on Day 3 (range 5.7-10.8 nM). Dissolved-Fe concentrations in Pacific water on Day 48 $(8.5 \mathrm{nM})$ were within the range of the mesocosms and also comparable to the nanomolar concentrations of dissolved Fe reported elsewhere in coastal surveys at shallow stations on the Peruvian Shelf (Bruland et al., 2005; Chever et al., 2015).

\subsection{Phytoplankton development}

Chl $a$ concentrations in the mesocosms were initially between 2.3 and $4.9 \mu \mathrm{g} \mathrm{L}^{-1}$ and declined to 1.4 to $2.4 \mu \mathrm{g} \mathrm{L}^{-1}$ on Day 8 (Fig. 5a). Initially, high values of chl $a$ were found mostly above 5 and below $15 \mathrm{~m}$ (Fig. 5b). The OMZ water addition increased chl $a$ to $3.7-5.6 \mu \mathrm{g} \mathrm{L}^{-1}$ (mesocosmspecific averages between Day 12 and Day 40) except for M3 where concentrations increased with a 1-week delay (3.4 $\mu \mathrm{g} \mathrm{L}^{-1}$ between Day 22 and Day 36) and M4 where concentrations remained at $1.6 \mu \mathrm{g} \mathrm{L}^{-1}$ (average between Day 12 and Day 40; Fig. 5a). The chl $a$ maximum remained in the upper $5 \mathrm{~m}$ in the week after the OMZ water addition, but shifted to the intermediate depth range of between 5 and $15 \mathrm{~m}$ thereafter and remained there until approximately Day 40 . (Please note that the "quenching effect" can reduce in situ fluorometric chl $a$ values especially near the surface so that absolute values may be biased; Holm-Hansen et al., 2000.) The exception was M4 where no such pronounced maximum was observed at intermediate depths (Fig. 5b). Chl $a$ increased in all mesocosms, except for M4, to values of up to $38 \mu \mathrm{g} \mathrm{L}^{-1}$ after Day 40 (Fig. 5a). This bloom occurred in the upper $\sim 5 \mathrm{~m}$ of the water column, due to surface eutrophication by defecating seabirds (Inca tern, Larosterna inca), who discovered the mesocosms as a suitable resting place (see Sect. 4.1). Chl $a$ in the Pacific water was initially within the range enclosed inside the mesocosms, and concentrations increased to slightly higher values around the same time as in the mesocosms (Fig. 5). Throughout the study, chl $a$ in the Pacific water was between 1.2 and $10.6 \mu \mathrm{g} \mathrm{L}^{-1}$ with the chl $a$ maxima always above $10 \mathrm{~m}$ (Fig. 5b).

The phytoplankton community composition was determined based on pigment concentration ratios using CHEMTAX (Figs. 6, S1). We distinguished between seven phytoplankton classes: Chloro-, Dino-, Crypto-, Cyano-,
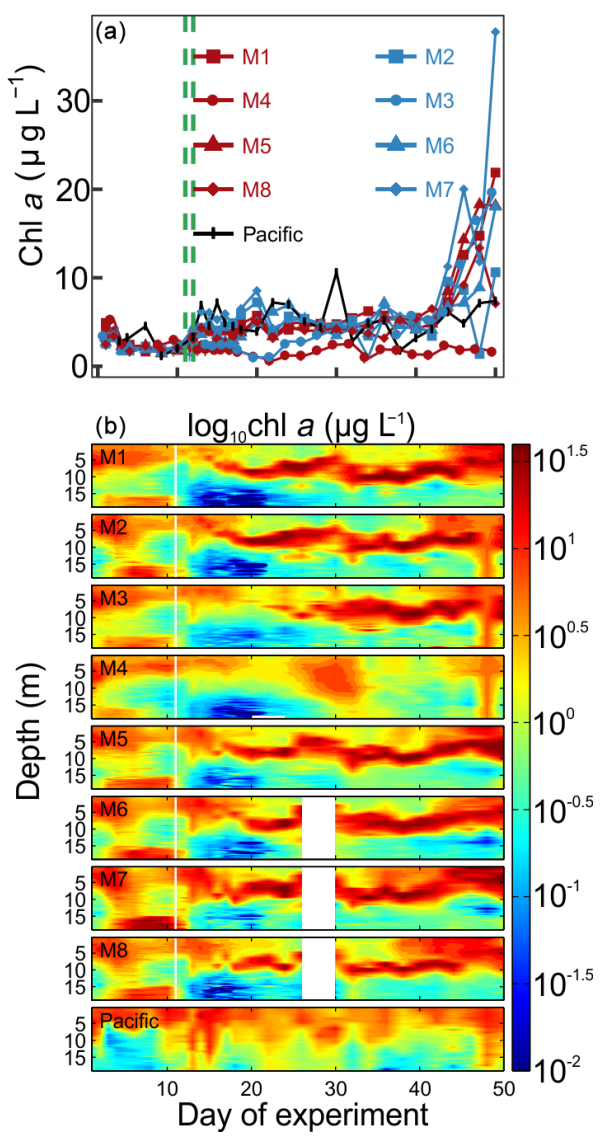

Figure 5. Chlorophyll a concentrations. (a) Average chl $a$ concentrations over the entire water column (0-17 m) measured by HPLC. (b) Vertical distribution of chl $a$ determined with the CTD fluorescence sensor on a logarithmic scale. The offset of the CTD sensor was corrected with the HPLC chl $a$ data. Please note, however, that the quenching effect may have influenced in situ fluorometric chl $a$ near the surface.

Prymnesio-, Pelago-, and Bacillariophyceae (i.e., diatoms) and use the word "dominant" in the following when a group contributes $>50 \%$ to chl $a$. Diatoms initially dominated the community and contributed $50 \%-59 \%$ of the total chl $a$ concentration but declined after the start while Chlorophyceae (or Dinophyceae in M1 and M7) became more important. The other groups contributed mostly $<25 \%$ to chl $a$ before the OMZ water addition. Diatoms contributed marginally to the chl $a$ increase in the days after the addition. Instead, Dinophyceae became dominant in most mesocosms and contributed between $64 \%$ and $76 \%$ of the total chl $a$ until the end of the experiment (range based on averages between Day 12 and Day 50 excluding M3 and M4). Imaging flow cytometry and microscopy revealed that the dinoflagellate responsible for this dominance was the large $(\sim 60 \mu \mathrm{m})$ mixotrophic species Akashiwo sanguinea (Bernales et al., 2020). The A. sanguinea bloom was delayed by $\sim 10 \mathrm{~d}$ in M3, and they remained absent in M4 throughout the study. 

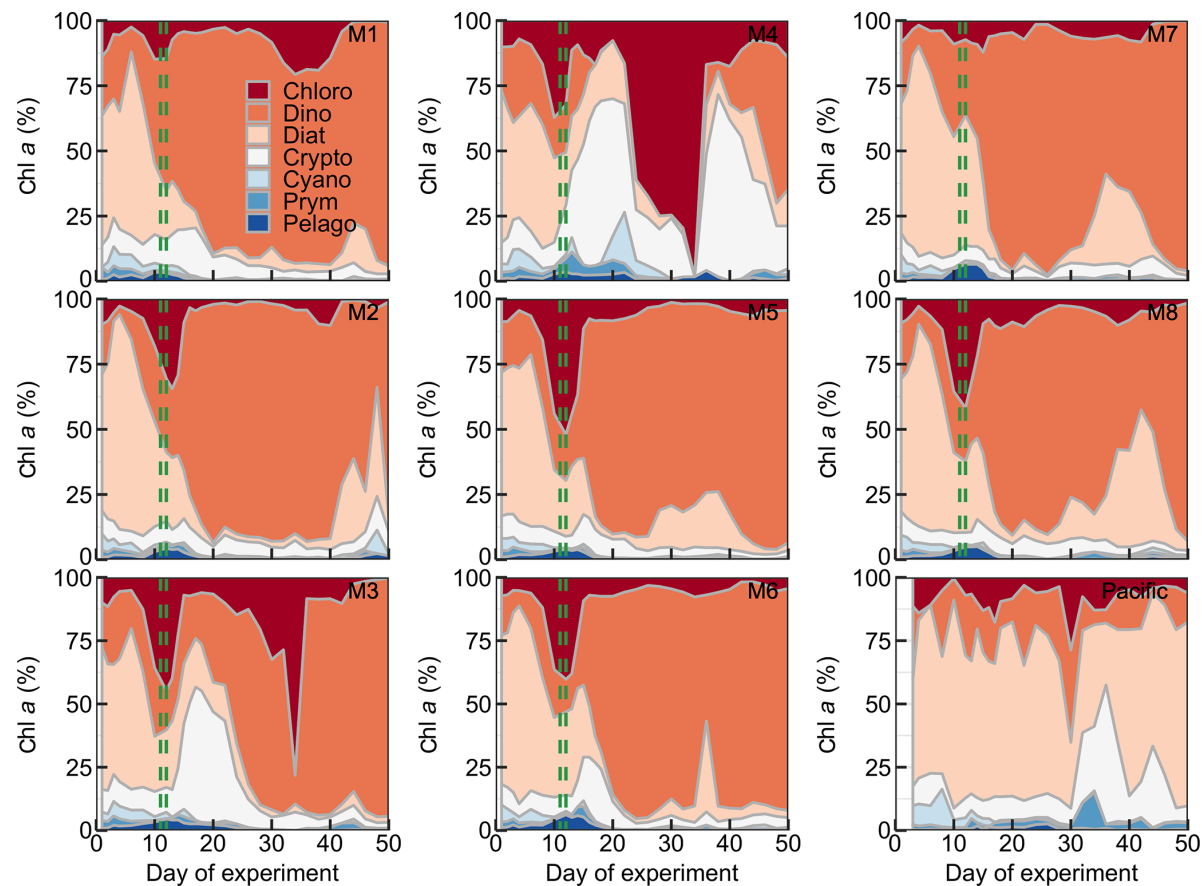

Figure 6. Relative contribution of the different phytoplankton classes to the total chl $a$ concentration. The mesocosm number is given on the top right of each subplot. The dashed green lines mark the days of OMZ water additions.

Cryptophyceae benefited from the absence of A. sanguinea and were the dominant group in M3 and M4 in the $\sim 10 \mathrm{~d}$ after the OMZ water addition (Fig. 6). Chlorophyceae were detectable in all mesocosms after the OMZ water addition with relatively low chl $a$ contribution except for M1, M3, and M4 where they contributed up to $21 \%, 78 \%$, and $98 \%$, respectively. Cyano-, Prymnesio-, and Pelagophyceae made hardly any contribution to chl $a$ after the OMZ water addition (average $<3 \%$ ) except for M4 where they were slightly more important (average $=7 \%$ ). Diatoms formed blooms in some mesocosms after Day 30 where they became more important for relatively short times (M2, M5, M7, M8). The phytoplankton community composition in the Pacific water differed from that in the mesocosms. Here, diatoms were dominant throughout the study period except for two very short periods where either Chlorophyceae + Dinophyceae (Day 30) or Cyanophyceae + Cryptophyceae dominated (Day 36; Fig. 6).

\subsection{Particulate matter pools and export fluxes}

POC concentrations in the mesocosm water columns ( $\mathrm{POC}_{\mathrm{WC}}$ ) were initially between 49 and $66 \mu \mathrm{mol} \mathrm{L}^{-1}$ and declined following the $\mathrm{OMZ}$ water addition to $32-54 \mu \mathrm{mol} \mathrm{L} \mathrm{L}^{-1}$ on Day 16. $\mathrm{POC}_{\mathrm{WC}}$ started to increase after Day 16, and POC $_{W C}$ reached a new steady state of $75-116 \mu \mathrm{mol} \mathrm{L}^{-1}$ between Day 24 and Day 44. Exceptions were M3 and M4 where the increase either was delayed (M3) or did not take place at all (M4). $\mathrm{POC}_{\mathrm{WC}}$ increased rapidly at the end of the experiments (Fig. 7a). POC $\mathrm{WC}_{\mathrm{C}}$ in the Pacific water was between 34 and $72 \mu \mathrm{mol} \mathrm{L}^{-1}$ between Day 0 and Day 24 and decreased thereafter to values of between 27 and $55 \mu \mathrm{mol} \mathrm{L}^{-1}$ (Fig. 7a). The accumulation of POC in the sediment traps $(\Sigma \mathrm{POC}$ ST) was surprisingly constant over the course of the study, with an average rate of $1.06 \mu \mathrm{mol}$ POC L ${ }^{-1} \mathrm{~d}^{-1}$ (Fig. 7c).

PON ${ }_{W C}$ concentrations in the mesocosms were initially between 9.2 and $11.9 \mu \mathrm{mol} \mathrm{L}^{-1}$ and declined after the OMZ water addition to $6.2-10.3 \mu \mathrm{mol} \mathrm{L}^{-1}$ on Day 16. The increase in $\mathrm{PON}_{\mathrm{WC}}$ to $8.4-18.1 \mu \mathrm{mol} \mathrm{L}^{-1}$ during days 17 24 was much less pronounced compared to $\mathrm{POC}_{\mathrm{WC}}$ (compare Fig. 8a and b). Furthermore, M3 and M4 were not markedly different from the other mesocosms during this period. However, M4 was the only mesocosm where PON $\mathrm{WC}_{\mathrm{WC}}$ declined profoundly after Day 30 and remained at a lower level until the end. PON ${ }_{W C}$ in all other mesocosms remained at $5-18.1 \mu \mathrm{mol} \mathrm{L}{ }^{-1}$ between Day 24 and Day 42 but increased markedly towards the end of the experiment (Fig. 7b). PON $\mathrm{WC}_{\mathrm{WC}}$ in the Pacific water varied between 7.9 and $16.2 \mu \mathrm{mol} \mathrm{L}^{-1}$ between Day 0 and Day 30 and between 4.8 and $9.6 \mu \mathrm{mol} \mathrm{L}^{-1}$ from Day 32 until the end of the experiment. $\Sigma \mathrm{PON}_{\mathrm{ST}}$ accumulation was, like $\Sigma \mathrm{POC}_{\mathrm{ST}}$, relatively constant over time, averaging at a rate of $0.15 \mu \mathrm{mol}$ PON L ${ }^{-1} \mathrm{~d}^{-1}$ (Fig. 7d).

BSi ${ }_{W C}$ concentrations in the mesocosms were initially 2.5-3.7 $\mu \mathrm{mol} \mathrm{L}^{-1}$ but decreased after the OMZ water addition to $0.4-0.8 \mu \mathrm{mol} \mathrm{L}^{-1}$ on Day 26. They remained at these low levels until the end of the experiment with smaller peaks 

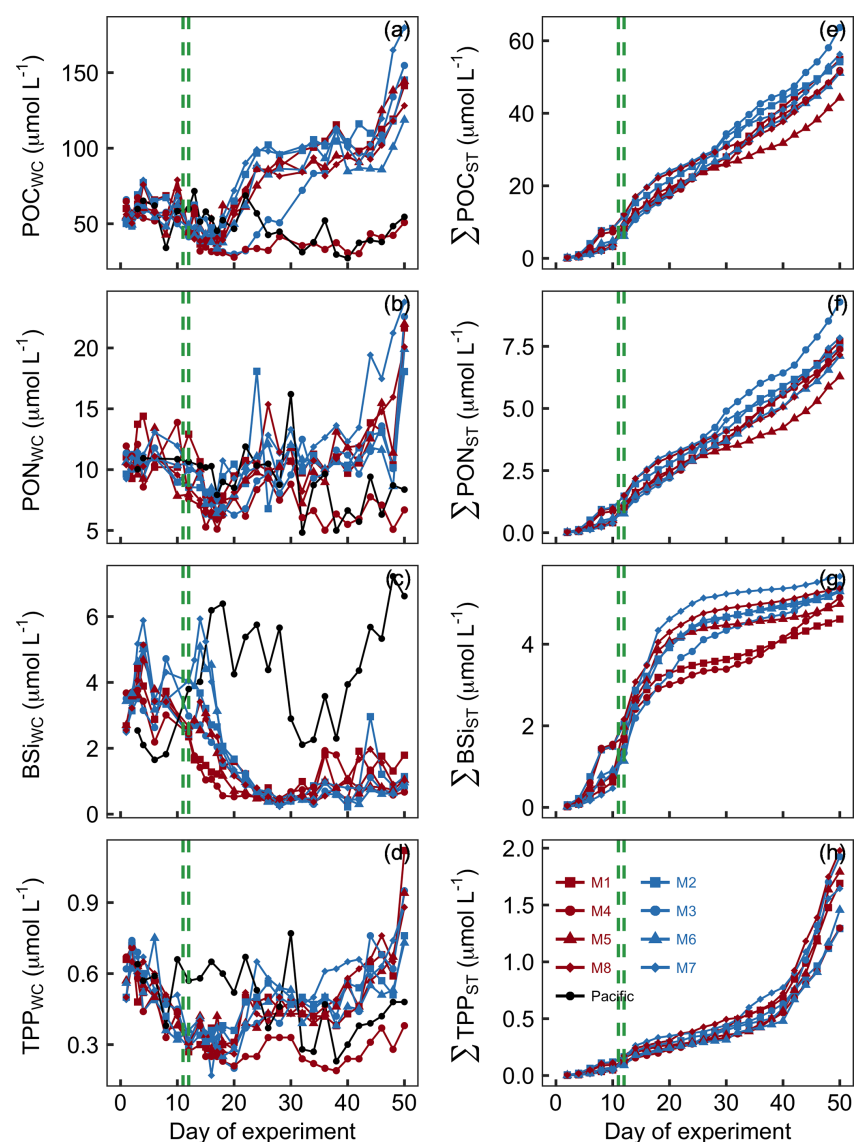

Figure 7. Particulate organic matter concentrations and cumulative export. Shown in panels (a)-(d) are concentrations averaged over the entire water column $(0-17 \mathrm{~m})$. Shown in panels $(\mathbf{e})-(\mathbf{h})$ are cumulative export fluxes of particulate matter over the course of the study. The green lines mark the days of OMZ water additions.

in some mesocosms due to minor diatom blooms (compare Figs. 8d and 6). The BSi ${ }_{W C}$ development in the Pacific water was very different from that in the mesocosms. Here, BSiwC was initially lower but increased to 6.4 between Day 0 and Day 18. Afterwards it decreased for a short period but increased again towards the end of the experiment (Fig. 7c). $\Sigma$ BSist accumulation was high in the first 3 weeks when diatoms were still relatively abundant $\left(0.22 \mu \mathrm{mol} \mathrm{BSi} \mathrm{L}^{-1} \mathrm{~d}^{-1}\right)$ but very low thereafter $\left(0.04 \mu \mathrm{mol} \mathrm{BSi} \mathrm{L}^{-1} \mathrm{~d}^{-1}\right.$; Fig. $\left.7 \mathrm{~g}\right)$.

TPP $\mathrm{WC}_{\mathrm{C}}$ concentration decreased from $0.49-0.67$ on Day 0 to $0.27-0.36 \mu \mathrm{mol} \mathrm{L}^{-1}$ on Day 12 and remained around this level until Day 20. Afterwards, TPP ${ }_{W C}$ increased rapidly in all mesocosms except M4 to a new level of between 0.37 and $0.65 \mu \mathrm{mol} \mathrm{L}^{-1}$ until Day 24. TPP $\mathrm{WC}_{\text {increased al- }}$ most exponentially in all mesocosms from Day 38 until the end of the experiment. TPP ${ }_{\mathrm{WC}}$ was variable in the $\mathrm{Pa}$ cific water but generally higher between Day 0 and Day 30 $\left(0.37-0.77 \mu \mathrm{mol} \mathrm{L}^{-1}\right)$ than from Day 32 until the end $(0.28$ $0.43 \mu \mathrm{mol} \mathrm{L}^{-1}$; Fig. 7 d). $\Sigma \mathrm{TPP}_{\mathrm{ST}}$ accumulation was constant at a rate of about $0.015 \mu \mathrm{mol} \mathrm{TPPL} \mathrm{L}^{-1} \mathrm{~d}^{-1}$ until Day 40
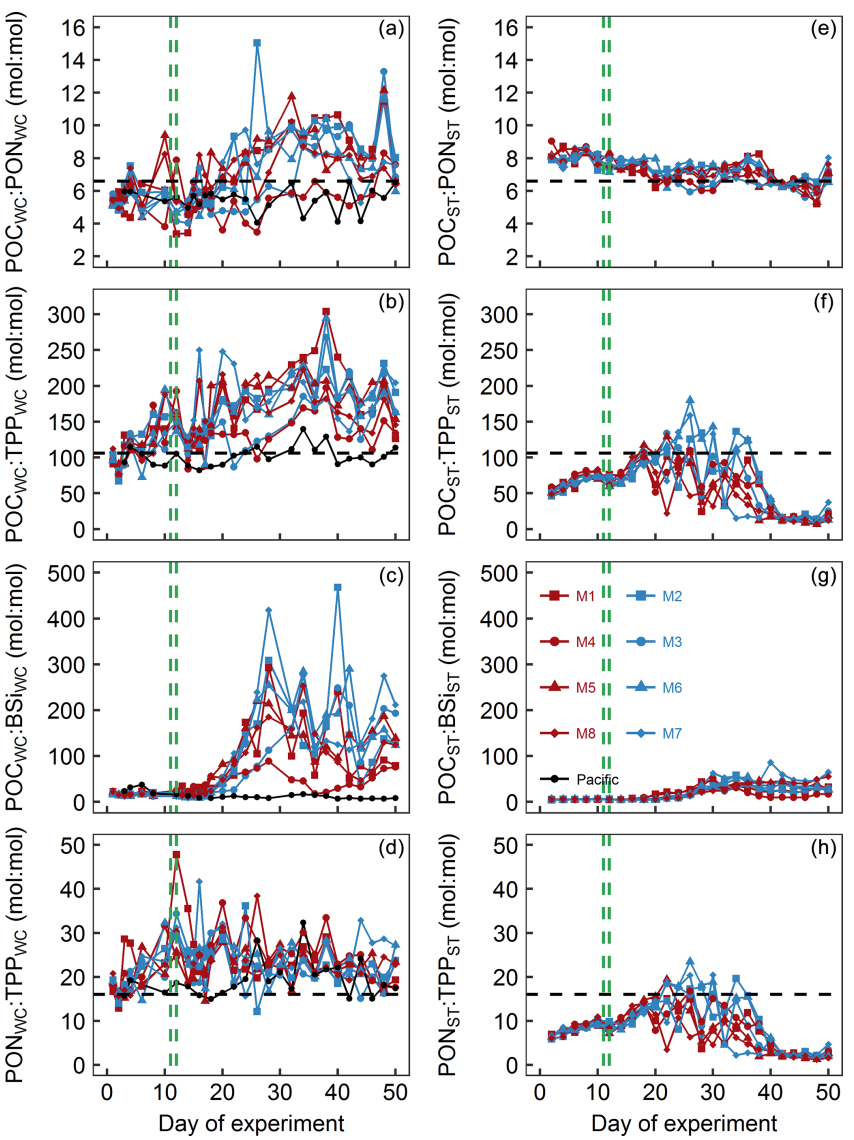

Figure 8. Particulate matter stoichiometry. Shown in panels (a)(d) are elemental ratios of particulate matter in the water column. Panels (e)-(h) show the same ratios but for particulate matter collected in the sediment traps. The horizontal dashed black lines display Redfield ratios (i.e., $\mathrm{POC}: \mathrm{PON}=6.6, \mathrm{POC}: \mathrm{TPP}=106$, $P O N$ : TPP $=16$ ). The vertical dashed green lines mark the days of OMZ water additions.

but increased sharply to $0.1 \mu \mathrm{mol} \mathrm{TPPL} \mathrm{L}^{-1} \mathrm{~d}^{-1}$ thereafter (Fig. 7h).

\subsection{Particulate organic matter stoichiometry}

$\mathrm{POC}_{\mathrm{WC}}: \mathrm{PON}_{\mathrm{WC}}$ in the mesocosms was initially between 5.1 and 5.8 and thus below the Redfield ratio (6.6). $\mathrm{POC}_{\mathrm{WC}}$ : $\mathrm{PON}_{\mathrm{WC}}$ remained at approximately these values until some days after the OMZ water addition when it increased to 7.9-11.8 in all mesocosms except for M3 and M4. In M3, the increase was delayed by about a week, whereas in M4 it remained at a lower level of 3.5-8.3 throughout the experiment. $\mathrm{POC}_{\mathrm{WC}}$ : $\mathrm{PON}_{\mathrm{WC}}$ decreased during the last $10 \mathrm{~d}$ of the study in all mesocosms except for M4 (Fig. 8a). POC $_{\mathrm{WC}}$ : $\mathrm{PON}_{\mathrm{WC}}$ in the Pacific water remained at around the initial value of 6 throughout the study (Fig. 8a). $\mathrm{POC}_{\mathrm{ST}}$ : $\mathrm{PON}_{\mathrm{ST}}$ ratios were considerably less variable than $\mathrm{POC}_{\mathrm{WC}}$ : $\mathrm{PON}_{\mathrm{WC}}$. They were initially $7.9-9$ and therefore higher than in the water column but decreased steadily over 
the course of the experiment, so they became lower than in the water columns in all mesocosms except M4 from around Day 30 onwards (Fig. 8e).

$\mathrm{POC}_{\mathrm{WC}}: \mathrm{TPP}_{\mathrm{WC}}$ in the mesocosms was initially close to the Redfield ratio (i.e., 106) but increased quite steadily up to 182-304 until Day 38 except for a short decline after the OMZ water addition. The increase was also apparent in M3 and M4, although it was less pronounced and there was little change in the 2 weeks after the OMZ water addition. POC $\mathrm{WC}_{\mathrm{C}}$ : TPP $\mathrm{WC}_{\mathrm{WC}}$ decreased from days 40 to 44 when it reached values of between 125 and 177 and remained approximately there (Fig. 8b). POC $\mathrm{WC}_{\mathrm{C}}$ : TPP $\mathrm{WC}_{\mathrm{W}}$ was much more stable in the Pacific water and relatively close to the Redfield ratio throughout the experiment (Fig. 8b). POC $\mathrm{ST}$ : $\mathrm{TPP}_{\mathrm{ST}}$ was always considerably lower than POC $_{\mathrm{WC}}$ : TPP $\mathrm{WC}_{\mathrm{WC}}$ (compare Fig. $8 \mathrm{~b}$ and $\mathrm{f}$ ). POC $_{S T}:$ TPP $_{\mathrm{ST}}$ increased in all mesocosms from initially 46-59 to 88-117 on Day 18, after which it varied widely between mesocosms. POC $\mathrm{ST}_{\mathrm{SP}}$ : $\mathrm{TPT}_{\mathrm{ST}}$ converged to a much narrower and very low value of between 7 and 42 from Day 40 until the end (Fig. 8f).

$\mathrm{POC}_{\mathrm{WC}}: \mathrm{BSi}_{\mathrm{WC}}$ in the mesocosms was between 8 and 34 from the start until Day 16 but increased substantially to 88418 until Day 28 and remained at a high level until the end of the experiment. The increase in POC ${ }_{W C}$ : BSiWC was slightly delayed in M3 and generally less pronounced in M4 (Fig. 8c). POC ${ }_{W C}: B_{W C}$ in the Pacific water remained at a low level of 7-38 throughout the experiment (Fig. 8c). $\mathrm{POC}_{\mathrm{ST}}$ : $\mathrm{BSi}_{\mathrm{ST}}$ also increased from 4-7 (until Day 16) to 4-86 (Day 18 until end) but was generally much lower than in the water column throughout the study (compare Fig. 8c and g).

$\mathrm{PON}_{\mathrm{WC}}: \mathrm{TPP}_{\mathrm{WC}}$ in the mesocosms was initially close to the Redfield ratio (i.e., 16) but increased to 19-36 until the OMZ water addition. Afterwards, PON ${ }_{W C}$ : TPP ${ }_{W C}$ fluctuated around this elevated value with a slight tendency to decrease until the end of the experiment (Fig. 8d). PON ${ }_{W C}:$ TPP $_{W C}$ in the Pacific water was $15-20$ and thus mostly above the Redfield ratio until Day 24, but the positive offset increased to 15-32 thereafter (Fig. 8d). PON ST $_{\text {: TPP }}$ was considerably lower than $\mathrm{PON}_{\mathrm{WC}}$ : $\mathrm{TPP}_{\mathrm{WC}}$ and below the Redfield ratio almost throughout the experiment. Its temporal development resembled the development of $\mathrm{POC}_{\mathrm{ST}}$ : TPP $\mathrm{ST}$ (compare Fig. 8f and h). It increased steadily from 6-7 at the beginning to $12-15$ on Day 18 , followed by a phase of large variability between mesocosms until Day $40 . \mathrm{PON}_{\mathrm{ST}}$ : TPP $\mathrm{ST}$ declined to 1-5 afterwards and remained at this low range level until the end of the experiment (Fig. 8h).

\section{Discussion}

\subsection{Small-scale variability, OMZ water signature similarities, and defecating seabirds - lessons learned from a challenging in situ mesocosm study during coastal El Niño 2017}

A key prerequisite to comparing different mesocosm treatments is the enclosure of identical water masses in all mesocosms at the beginning of the study (Spilling et al., 2019). Unfortunately, this was not particularly successful in our experiment as can be seen for example in the differences in initial inorganic nutrient concentrations (Fig. 4). Although our procedure of lowering the mesocosms bags and allowing for several days of water exchange does not exclude heterogeneity entirely (Bach et al., 2016a; Paul et al., 2015; Schulz et al., 2017), it was not as pronounced during our previous studies as experienced in Peru. The reason for this was likely the inherent small-scale patchiness of physicochemical conditions in the near coastal parts of EBUS (Chavez and Messié, 2009). We encountered small foamy patches with an $\mathrm{H}_{2} \mathrm{~S}$ smell indicative of submesoscale upwelling of anoxic waters, ultra-dense meter-sized swarms of zooplankton coloring the water red, and brownish filaments of discharging river water from the nearby Rímac River which carried large amounts of water due to flooding during the coastal El Niño (Garreaud, 2018). In such extraordinarily variable conditions, the mesocosms should be deployed and sealed in a very short time when conditions in the study site are relatively homogeneous. Alternatively, larger variability can be taken into account by increasing the number of replicates, but this was not feasible in our case due to the costs of a mesocosm unit of this size.

A major motivation for our experiment was to investigate how plankton communities in the coastal upwelling system off Peru would respond to upwelling of OMZ waters with different $\mathrm{N}: \mathrm{P}$ signatures (question 2 mentioned in the introduction). The rationale for this was that projected spatial extensions of OMZs and intensification of their oxygen depletion in a future ocean could enhance the $\mathrm{N}$ deficit in the study region with strong implications for ecological and biogeochemical processes (García-Reyes et al., 2015; Stramma et al., 2010). However, there was unusually little bioavailable inorganic $\mathrm{N}$ in both $\mathrm{OMZ}$ water masses so the differences in inorganic $\mathrm{N}: \mathrm{P}$ signatures between the two treatments were significant but small (Table 1; Fig. 4g). Because the differences were small, we decided to focus the present paper on the analyses of temporal developments. However, other publications in this special issue on the Peru mesocosm project will also have a closer look into treatment differences.

Another complicating factor during the experiment was the presence of Inca terns (Larosterna inca) - an abundant seabird species in the study region that began to roost in the limited space between the antibird spikes we installed on the mesocosm roofs (see video by Boxhammer et al., 2019). Until Day 36, their presence was occasional, but it increased 
profoundly thereafter. Additional bird scarers installed on Day 37 were unfortunately ineffective, and during the last 2 weeks of the study, we often counted more than 10 individuals on each mesocosm. It was evident that they defecated into the mesocosms as there was excrement on the inner side of the bags above the surface.

To get a rough estimate of the nutrient inputs through this "orni-eutrophication" in the mesocosms, we first assumed that the increase in TPP export after Day 40 is sinking excrement $\mathrm{P}$ (Fig. 7h). This assumption is reasonable because $\mathrm{PO}_{4}^{3-}$ was far from limiting and did not show any noticeable change in concentration during this time (Fig. 4b). Correcting the TPP export after Day 40 $\left(0.1 \mu \mathrm{mol} \mathrm{L} \mathrm{L}^{-1} \mathrm{~d}^{-1}\right)$ with the background value of the time before $\left(0.015 \mu \mathrm{mol} \mathrm{L}^{-1} \mathrm{~d}^{-1}\right)$ yields $0.085 \mu \mathrm{mol} \mathrm{L}^{-1} \mathrm{~d}^{-1}$ of $\mathrm{P}$ inputs from Inca terns. This converts to $1.15 \mu \mathrm{mol} \mathrm{L}^{-1} \mathrm{~d}^{-1}$ of $\mathrm{N}$ inputs, assuming a 13.5:1 N:P stoichiometry as reported for South American seabird excrements (Otero et al., 2018). This estimation is in reasonable agreement with the observed $\mathrm{PON}_{\mathrm{WC}}+\mathrm{DON}+\mathrm{NH}_{4}^{+}$increase of 5.2-17 $\mu \mathrm{mol} \mathrm{L}^{-1}$ observed from days 40 to 50 (Figs. $4 \mathrm{~d}$, e, and $8 \mathrm{~b}$; note that $\mathrm{PON}_{\mathrm{ST}}$ as well as $\mathrm{NO}_{x}^{-}$is considered to remain constant in this approximation; Figs. $4 \mathrm{a}$ and $8 \mathrm{f}$ ). These $\mathrm{N}$ inputs into the mesocosms are at least 5 orders of magnitude higher than what seabirds typically add to the water column of the Pacific in this region (Otero et al., 2018). Accordingly, the phytoplankton bloom that occurred in the upper $5 \mathrm{~m}$ after Day 40 was fueled by orni-eutrophication. While this certainly is an undesired experimental artifact, it had some advantages for interpreting the data as is highlighted in Sect. 4.2.1.

The coastal El Niño that climaxed during our experiment (Garreaud, 2018) is the last peculiarity we want to highlight in this section. Coastal El Niño events are rare with similar phenology to usual El Niño events that are regionally restricted to the far eastern Pacific. The last such event of similar strength occurred in 1925 (Takahashi and Martínez, 2019). Surface water temperatures (upper $5 \mathrm{~m}$ ) are mostly below $20^{\circ} \mathrm{C}$ in this region during non El Niño years (Graco et al., 2017) but were $20-25^{\circ} \mathrm{C}$ for most of the time during our study (Fig. 3a). This may have influenced metabolic processes of plankton and also enhanced stratification. Thus, it is possible that the observed conditions discussed in the following sections may not be entirely representative for the more common non-El Niño conditions.

\subsection{Factors controlling production and export}

Messié and Chavez (2015) identified light, macronutrient, and iron supply and transport processes (e.g., subduction) to be the key factors regulating primary and export production in EBUS. We can immediately exclude transport processes and iron concentration from having played a major role in our study. Transport processes above the microscale are excluded in mesocosms. Iron concentrations are elevated to nanomolar concentrations in shallow waters along the Peruvian shelf
(Bruland et al., 2005) generally leading to a sharp contrast between Fe-limited (or co-limited) offshore ecosystems and Fe-replete conditions in highly productive inshore regions (Browning et al., 2018; Hutchins et al., 2002). DissolvedFe concentrations were verified to be high in the mesocosms both in surface and subsurface waters throughout the experiment (days 3, 17, 48; Table S1) confirming that Fe was replete compared to $\mathrm{N}$. Thus, our subsequent discussion will only consider light and macronutrients (mostly $\mathrm{N}$ because $\mathrm{P}$ was also replete) as well as phytoplankton community composition as controlling factors of production and export.

\subsubsection{Production}

A remarkable observation is the decline in chl $a$ during the first $5 \mathrm{~d}$ despite high and decreasing nutrient concentrations (Figs. 4 and 5). We explain this with the unusually high light attenuation in the water column that was caused by a high standing stock of biomass in the surface layer (Fig. 3c). Integrated surface layer nutrient samples $(0-5$ or $0-10 \mathrm{~m}$; Sect. 2.4, data not shown) indicated that inorganic $\mathrm{N}$ was exhausted early in the experiment in the upper $\sim 5 \mathrm{~m}$ of the water column where light availability was relatively high (Fig. 3c). Accordingly, growth in the upper $\sim 5 \mathrm{~m}$ was dependent on the limited $\mathrm{N}$ supply that had to come from below via mixing. Conversely, phytoplankton growth was likely lightlimited due to self-shading below $\sim 5 \mathrm{~m}$ where inorganic $\mathrm{N}$ was sufficiently available during the first $20 \mathrm{~d}$ of the experiment. Thus, we conclude that phytoplankton production was $\mathrm{N}$-limited in the upper $\sim 5 \mathrm{~m}$ and light-limited below, so loss processes (e.g., grazing and sedimentation), when integrated over the entire water column, may have outweighed production. Indeed, there is a conspicuous chl $a$ peak in the funnels of the terminal sediment traps from days 3 to 10 which points towards sinking of phytoplankton cells below the euphotic zone (Fig. 5b) - a loss process that may have been amplified by the enclosure of the water column inside the mesocosms where turbulence is reduced.

Dinophyceae, represented by the dinoflagellate $A$. sanguinea, formed blooms in most mesocosms after the OMZ water addition when most inorganic $\mathrm{N}$ sources were already exhausted. This implies that A. sanguinea, a facultative osmotroph (Kudela et al., 2010), extracted limiting $\mathrm{N}$ from the DON pool, consistent with the decline in DON during days $15-25$ (Fig. 4e). The blooms of $A$. sanguinea were associated with a profound increase in POC (Fig. 7a) and DOC of about $50 \mu \mathrm{mol} \mathrm{L} \mathrm{L}^{-1}$ for both and a concomitant decrease in dissolved inorganic carbon (DIC) of $\sim 100 \mu \mathrm{mol} \mathrm{L}^{-1}$ (DOC data shown by Igarza et al., 2020; DIC data shown by Chen et al., 2020). This is consistent with a considerable $\mathrm{dO}_{2}$ increase above $100 \%$ saturation in those mesocosms harboring A. sanguinea (all except M4). Altogether, these data suggest that $A$. sanguinea made a large contribution to the POC increase observed in the mesocosms. 
Another interesting observation with respect to $A$. sanguinea was its long persistence in the water columns. It consistently contributed the majority of chl $a$ after it had become dominant in the mesocosms (Figs. 6, S1) and even persisted during the orni-eutrophication event where other phytoplankton exploited the surface eutrophication and generated additional POC (Fig. 7a). Importantly, A. sanguinea contributed to a high level of chl $a$ even after the buildup of POC and DOC and the concomitant draw-down of DIC, roughly between Day 15 and Day 25, had stopped (Fig. 7a; DOC data shown by Igarza et al., 2020; DIC data shown by Chen et al., 2020). This observation highlights the difficulties when assessing production from chl $a$ (e.g., through remote sensing) because mixotrophic species like $A$. sanguinea may conserve high pigment concentrations even when photosynthetic rates are low.

Orni-eutrophication during the last $10 \mathrm{~d}$ enabled rapid phytoplankton growth through the relief from $\mathrm{N}$-limitation in the upper $\sim 5 \mathrm{~m}$ where light availability was relatively high (Fig. 3c). Grazers could apparently not control such rapid growth so that phytoplankton growth led to a substantial chl $a$ buildup. The fact that the bloom occurred near the surface highlights the role of light limitation in the coastal Peruvian upwelling system. It appears that self-shading due to high biomass is a key mechanism that constrains phytoplankton growth when integrated over the water column. This constraint may enable an equilibrium between production and loss processes as reflected in the relative constancy of chl $a$, POC $\mathrm{WC}_{\mathrm{C}}$ and $\mathrm{POC}_{\mathrm{ST}}$ (Figs. 5a and 8a, e; see next section for further details on export). Indeed, the orni-eutrophication demonstrates that when limiting nutrients are added to a layer with high light intensity, phytoplankton near the surface can break this equilibrium and grow rapidly (Figs. 5a, S2).

\subsubsection{Export flux}

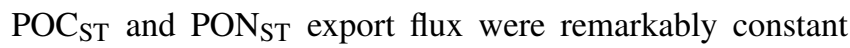
over the course of the study (Fig. 7e, f; the same applies for TPP $_{\mathrm{ST}}$ export until Day 40 when orni-eutrophication became significant, Fig. 7h). As for production, we assume the constancy to be rooted in the $\mathrm{N}$ and light co-limitation which limits pulses of rapid production and enables an equilibrium between production and export. Mechanistically, this may be explained by a relatively constant physical coagulation rate and/or a relatively constant grazer turnover establishing relatively constant biologically mediated aggregation and sinking (Jackson, 1990; Wassmann, 1997). Interestingly, M4 was not different to the other mesocosms even though the enormous $\mathrm{POC}_{\mathrm{WC}}$ buildup through $A$. sanguinea was absent (Fig. 7a, e). This observation implies a limited influence of A. sanguinea on export production over the duration of the experiment. However, it is likely that the biomass generated by $A$. sanguinea would have enhanced export flux when their populations started to decline and sink out. Unfortunately, we could not observe the A. sanguinea sinking event as we had to terminate the study (Day 50) before the population declined. Nevertheless, these findings allow us to conclude that the time lag between the A. sanguinea biomass buildup (Day $\sim 15$ ) and decline is at least $35 \mathrm{~d}$. This is an important observation as it implies that the production and export by these types of dinoflagellates can be uncoupled by more than a month - a factor that is often neglected in studies of organic matter export where production and export are generally assumed to be simultaneous (Laws and Maiti, 2019; Stange et al., 2017).

Another interesting aspect with respect to the constancy of the POC $\mathrm{PT}_{\mathrm{ST}}$ and $\mathrm{PON}_{\mathrm{ST}}$ export flux is the sharp decline in the BSisT export flux around Day 20 (Fig. 7g). This indicates that sustaining a constant $\mathrm{POC}_{\mathrm{ST}}$ and $\mathrm{PON}_{\mathrm{ST}}$ export flux did not depend on diatoms. Furthermore, cumulative $\Sigma$ BSisT $_{\text {ST }}$ and POC $_{\text {ST }}$ on Day 50 do not correlate across mesocosms, showing that increased $\Sigma B$ Si $_{\text {ST }}$ export does not necessarily enhance total $\Sigma \mathrm{POC}_{\mathrm{ST}}$ export (insignificant linear regression; data not shown). Thus, silicifiers had a (perhaps surprisingly) small influence on controlling $\mathrm{POC}_{\mathrm{ST}}$ export fluxes in this experiment.

\subsection{Particulate $\mathrm{C}: \mathrm{N}: \mathrm{P}:$ Si stoichiometry in the mesocosms}

\subsection{1 $C: N$}

POC $_{W C}: P_{W C}$ was mostly below the Redfield ratio (i.e., 6.6:1 mol : mol) until the OMZ water addition (Fig. 8a). The low values coincide with the initial dominance of diatoms, and these are known to have an inherently lower particulate C: N stoichiometry than dinoflagellates (Quigg et al., 2003). Yet, the absolute $\mathrm{POC}_{\mathrm{WC}}: \mathrm{PON}_{\mathrm{WC}}$ ratios are still at the lower end even for diatoms, indicating that the predominant species had particularly low $\mathrm{C}: \mathrm{N}$ ratios and/or that growth conditions (e.g., light limitation) led to a high $\mathrm{N}$ demand (Brzezinski, 1985; Terry et al., 1983). POC ST $_{\text {: PON }}$ was higher than $\mathrm{POC}_{\mathrm{WC}}$ : $\mathrm{PON}_{\mathrm{WC}}$ during the initial period, indicating preferential remineralization of $\mathrm{N}$ over $\mathrm{C}$.

After the OMZ water addition, $\mathrm{POC}_{\mathrm{WC}}$ : $\mathrm{PON}_{\mathrm{WC}}$ increased substantially due to the $A$. sanguinea bloom. The predominant control of $A$. sanguinea on $\mathrm{POC}_{\mathrm{WC}}$ : $\mathrm{PON}_{\mathrm{WC}}$ during this time is clear as we saw no increase in M4 where this species was absent and a delayed increase in M3 where the A. sanguinea bloom was delayed. Importantly, the increase in $\mathrm{POC}_{\mathrm{WC}}$ : $\mathrm{PON} \mathrm{NC}_{\mathrm{WC}}$ is not reflected in an increase in $\mathrm{POC}_{\mathrm{ST}}$ : $\mathrm{PON}_{\mathrm{ST}}$ (Fig. 8a, e). This strongly supports our interpretations in Sect. 4.2.2 that A. sanguinea did not notably contribute to export production before the experiment was terminated because otherwise we would have expected the high $\mathrm{POC}_{\mathrm{WC}}: \mathrm{PON}_{\mathrm{WC}}$ signal to occur in the sediment traps as well.

During the last $10 \mathrm{~d}$, both $\mathrm{POC}_{\mathrm{WC}}$ : $\mathrm{PON}_{\mathrm{WC}}$ and $\mathrm{POC}_{\mathrm{ST}}: \mathrm{PON}_{\mathrm{ST}}$ declined despite the ongoing prevalence of A. sanguinea. The decline was potentially triggered 
by the orni-eutrophication event which fertilized a bloom with new nutrients in the upper $\sim 5 \mathrm{~m}$ of the water column and lead to the production and export of more N-rich organic material.

\subsubsection{C:P}

POC $_{\mathrm{WC}}: \mathrm{TPP}_{\mathrm{WC}}$ was initially close to the Redfield ratio (i.e., 106:1 mol : mol) but started to increase early on in all mesocosms until around Day 40 (with a minor decrease after the OMZ water addition; Fig. 8b). The increase was less pronounced but also present in M4 where A. sanguinea did not bloom. This suggests that $A$. sanguinea was the main driver of this trend but other players in the plankton communities responded similarly with respect to the direction of change. Interestingly, there was a tendency of decreasing POC $\mathrm{WC}_{\mathrm{W}}$ : TPP $\mathrm{WC}_{\mathrm{WC}}$ during periods of chl $a$ increase which may be due to the cells acquiring $\mathrm{P}$ for cell divisions (Klausmeier et al., 2004).

POC $_{\mathrm{ST}}: \mathrm{TPP}_{\mathrm{ST}}$ was considerably lower than POC $\mathrm{WC}_{\mathrm{C}}: \mathrm{TPP}_{\mathrm{WC}}$ throughout the experiment, indicative of the unusual observation of preferential remineralization of $\mathrm{C}$ over $\mathrm{P}$ in the water column. The extremely low POC $_{S T}$ : TPP $_{S T}$ values recorded during the last $10 \mathrm{~d}$ of the experiment are very likely due to the orni-eutrophication when defecated P sank unutilized into the sediment traps.

\subsubsection{C : $\mathrm{Si}$}

POC $\mathrm{WC}_{\mathrm{WC}}$ : BSiwC was initially low (Fig. 8c), indicative of a diatom-dominated community (Brzezinski, 1985). The increase in $\mathrm{POC}_{\mathrm{WC}}$ : $\mathrm{BSi}_{\mathrm{WC}}$ about a week after the OMZ water addition coincides roughly with the depletion of $\mathrm{NO}_{x}^{-}$even though $\mathrm{Si}(\mathrm{OH})_{4}$ was still available in higher concentrations (compare Figs. 4a, c and 9c). This suggests that the change from diatom to dinoflagellate predominance was triggered by $\mathrm{N}$ and not $\mathrm{Si}$ limitation. The $\mathrm{POC}_{\mathrm{WC}}: \mathrm{BSi}_{\mathrm{WC}}$ increase is lower in M4 where A. sanguinea was absent, underlining that this species was a key player driving the trend in the other mesocosms.

$\mathrm{POC}_{\mathrm{ST}}$ : $\mathrm{BSi}_{\mathrm{ST}}$ also increased after the $\mathrm{OMZ}$ water addition but the increase was considerably less pronounced than for $\mathrm{POC}_{\mathrm{WC}}$ : $\mathrm{BSi}_{\mathrm{WC}}$. Once again, the explanation for this is the persistence of $A$. sanguinea which maintains the high signal in the water column but does not transfer it to the exported material because it did not sink out during the experiment.

\subsubsection{N : $P$}

PON ${ }_{W C}:$ TPP $_{W C}$ was higher than the Redfield ratio (i.e., 16:1) almost throughout the entire experiment (Fig. 8d), although still within the range of what can be found in coastal regions (Sterner et al., 2008) and among phytoplankton taxa (Quigg et al., 2003). The large positive offset relative to the ratio of dissolved inorganic $\mathrm{N}: \mathrm{P}$, which was initially $8: 1-5: 1$ but then decreased to values of around
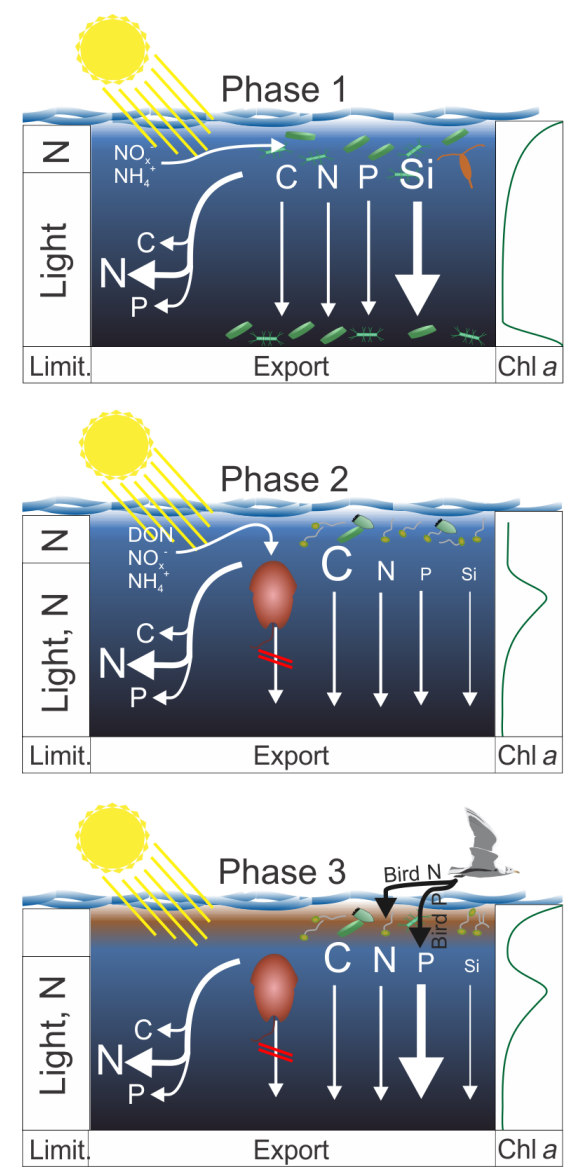

Figure 9. Synthesis graphic. The text in Sect. 5 functions as an extended figure caption and should be read to fully understand processes illustrated in this graphic. The left column indicates the factors limiting organic matter production in the upper $\sim 5 \mathrm{~m}$ and below. The arrows on the left identify which elements were remineralized preferentially during sinking. The arrows on the right indicate the export flux of these elements. In both cases strength is indicated by the arrow and letter sizes. The column on the right shows the approximate chl $a$ profile during the three phases. The brown phytoplankton drawn in pictures of Phase 2 and 3 illustrates $A$. sanguinea.

$0.1: 1$, likely reflects that the plankton community has a certain $\mathrm{N}$ requirement that is independent of the unusually high $\mathrm{P}$ availability. Hence, inorganic $\mathrm{N}$ : P may not be a suitable predictor of particulate $\mathrm{N}: \mathrm{P}$ under these highly $\mathrm{N}$-limited conditions.

Another interesting observation was that $\mathrm{PON}_{\mathrm{WC}}$ : TPP $\mathrm{WC}_{\mathrm{WC}}$ was increasing initially even though the inorganic nutrient $\mathrm{N}$ : $\mathrm{P}$ supply ratio was decreasing (compare Figs. $4 \mathrm{~g}$ and $9 \mathrm{~d}$ ). This observation is inconsistent with a previous shipboard incubation study in the Peruvian upwelling system (Franz et al., 2012b). We can only speculate about the opposing trend between inorganic $\mathrm{N}: \mathrm{P}$ and $\mathrm{PON}_{\mathrm{WC}}$ : TPP $\mathrm{WC}_{\mathrm{WC}}$ but consider changes in the phytoplankton species composition to be the most plausible explanation. Presumably, the transition from 
diatoms with intrinsically low $\mathrm{N}: \mathrm{P}$ towards Chlorophyceae and Dinophyceae with higher $\mathrm{N}: \mathrm{P}$ during the first $10 \mathrm{~d}$ may largely explain this observation (Quigg et al., 2003).

Not surprisingly, $\mathrm{PON}_{\mathrm{ST}}$ : $\mathrm{TPP}_{\mathrm{ST}}$ was lower than $\mathrm{PON}_{\mathrm{WC}}: \mathrm{TPP}_{\mathrm{WC}}$ indicating preferential remineralization of the limiting $\mathrm{N}$ over the replete $\mathrm{P}$ in the water column. Additionally, the $\mathrm{P}$ inputs from defecating birds during the last $10 \mathrm{~d}$ mostly sank out unutilized and further reduced the already low $\mathrm{PON}_{\mathrm{ST}}$ : $\mathrm{TPP}_{\mathrm{ST}}$.

\section{Synthesis}

This section synthesizes the most important patterns with respect to organic matter production, export, and stoichiometry. Based on the processes described in the discussion we subdivide the mesocosm experiment into three main phases (see Fig. 9 for a synthesis graphic).

Phase 1 lasts from Day 1 until the OMZ water addition (days 11 and 12) and describes what we consider the expected early-succession diatom-dominated community. Here, diatoms grow near the surface where they quickly exhaust inorganic N. Inorganic $\mathrm{N}$ is still available deeper in the water column, but low light availability limits growth rates, so loss processes are higher than gains. Loss is potentially due to grazing but also due to phytoplankton sedimentation as indicated by a sharp chl $a$ peak in the sediment trap funnels below $17 \mathrm{~m}$. The BSi export is relatively high, while the POC export is not, indicating that diatoms did not enhance organic matter export compared to other communities prevailing later in the experiment. The $\mathrm{C}: \mathrm{N}$ ratio of suspended matter is low, whereas the $\mathrm{C}: \mathrm{N}$ ratio of sinking material is higher, indicating the high $\mathrm{N}$ demand of the community (preferential remineralization of $\mathrm{N}$ ). This is supported by the low (i.e., much below the Redfield ratio) $\mathrm{N}: \mathrm{P}$.

Phase 2 lasts from the OMZ water addition until Day 40 and is characterized by the dominant influence of the mixotrophic dinoflagellate Akashiwo sanguinea. The transition from diatom to dinoflagellate domination was likely triggered by $\mathrm{N}$ limitation (Fig. 4a, d) and not Si limitation, which was available with $>6 \mu \mathrm{mol} \mathrm{L}{ }^{-1}$ during the transition (Fig. 4c). A. sanguinea became dominant about a week after the OMZ water addition. The A. sanguinea bloom was fueled by inorganic and organic nutrients and roughly doubled the amount of POC in the water column. However, the biomass formed by this species did not sink out in significant quantities and remained in the water column until the experiment was terminated. Thus, the export flux during the experiment was not different in mesocosms where A. sanguinea bloomed compared to the one mesocosm (M4) where this bloom did not occur, despite very large differences in production. These findings suggest that production and export by mixotrophic dinoflagellates can be temporarily highly uncoupled which is an important factor to consider when determining export ratios (i.e., export production/primary production). The $A$. sanguinea bloom also left a major imprint on particulate organic matter stoichiometry by increasing $\mathrm{C}: \mathrm{N}, \mathrm{C}: \mathrm{P}$, and $\mathrm{C}: \mathrm{Si}$.

Phase 3 lasts from Day 40 until the end of the experiment and is characterized by defecations of the seabird Larosterna inca (Inca tern) into the mesocosms. This orni-eutrophication relaxed the prevailing $\mathrm{N}$ limitation and triggered intense phytoplankton blooms in most mesocosms in the upper $\sim 5 \mathrm{~m}$ of the water column where the light availability was relatively high. $\mathrm{N}$ inputs through bird excrements were directly utilized and converted into organic biomass, whereas the defecated $P$ remained unutilized and sank through the water column directly into the sediment traps. A. sanguinea persisted during this bloom at intermediate depth $(\sim 10 \mathrm{~m})$, so the surface bloom added organic biomass to the already-available standing stock. Organic matter export (except for TPP) did not increase during the bloom, likely because the new biomass was still accumulating in the water column and the experiment was terminated before it started to sink out. The relaxed $\mathrm{N}$ limitation due to orni-eutrophication also decreased the $\mathrm{C}: \mathrm{N}$ ratio of suspended organic matter (increased $\mathrm{N}: \mathrm{P}$ ) relative to phase 2 .

Altogether, our study revealed that the combined influence of $\mathrm{N}$ limitation, light limitation via self-shading, and plankton community composition has a pronounced control of organic matter production, export, and stoichiometry in the coastal upwelling system off Peru. These findings improve our mechanistic understanding of key processes in this region and are valuable for modeling. The analysis provided in this paper covers many of the most noticeable outcomes of this experiment with respect to ecology and biogeochemistry. However, more specialized papers will be published within this Biogeosciences special issue that provide additional detail on important aspects including oceanographic conditions during the coastal El Niño, phyto- and zooplankton succession patterns, microbial diversity, enzyme activities, phytoplankton fatty-acid profiles, archaeal lipidomes, carbonate chemistry, community production and respiration, $\mathrm{N}_{2}$ fixation, $\mathrm{N}$ loss processes, DOC dynamics, $\mathrm{Si}$ isotope fractionation, and sinking velocity and export.

Data availability. The dataset is now available under https://doi.org/10.1594/PANGAEA.923395 (Bach et al., 2020).

Video supplement. The video supplement by Boxhammer et al. (2019; https://doi.org/10.3289/ORNI_EUTROPHICATION) visualizes the seabird "orni-eutrophication" event from days 40-50 by Inca terns (Larosterna inca).

Supplement. The supplement related to this article is available online at: https://doi.org/10.5194/bg-17-4831-2020-supplement. 
Author contributions. LTB, AJP, TB, KGS, MH, AL, SL, CSp, MS, and UR designed the experiment. LTB, AJP, TB, EvdE, KGS, IB, ASB, GC, SMC, KD, AF, MF, PG, MHa, JH, NHH, VK, LK, PK, CLi, SL, JaM, JuM, FM, JP, CSf, KS, CSp, MS, MZM, and UR contributed to the sampling. LTB, AJP, TB, EvdE, KGS, EA, JA, PAg, IB, AB, MHa, VK, JL, SL, AL, JaM, JuM, FM, CSf, and SS analyzed the data. LTB wrote the manuscript with comments from all co-authors.

Competing interests. The authors declare that they have no conflict of interest.

Special issue statement. This article is part of the special issue "Ecological and biogeochemical functioning of the coastal upwelling system off Peru: an in situ mesocosm study”. It is not associated with a conference.

Acknowledgements. We thank all participants of the KOSMOS Peru 2017 study for assisting in mesocosm sampling and maintenance. We are particularly thankful to the staff of IMARPE for their support during the planning, preparation, and execution of this study and to the captains and crews of BAP Morales, IMARPE VI, and BIC Humboldt for support during deployment and recovery of the mesocosms and various operations during the course of this investigation. Special thanks go to the Marina de Guerra del Perú, in particular the submarine section of the navy of Callao, and to the Dirección General de Capitanías y Guardacostas. We also acknowledge strong support for sampling and mesocosm maintenance by JeanPierre Bednar, Susanne Feiersinger, Peter Fritsche, Paul Stange, Anna Schukat, and Michael Krudewig. We want to thank Club Náutico Del Centro Naval for excellent hosting of our temporary filtration laboratory and office space and their great support and improvisation skills after two of our boats were lost. This work is a contribution in the framework of the cooperation agreement between IMARPE and GEOMAR through the German Federal Ministry of Education and Research (BMBF) project ASLAEL 12-016 and the national project Integrated Study of the Upwelling System off Peru developed by the Directorate of Oceanography and Climate Change of IMARPE, PPR 137 CONCYTEC.

Financial support. This research has been supported by the Collaborative Research Center SFB 754 Climate-Biogeochemistry Interactions in the Tropical Ocean financed by the German Research Foundation (DFG), the EU project AQUACOSM, and the Leibniz Award 2012 (granted to Ulf Riebesell).

Review statement. This paper was edited by Dimitri Gutierrez and reviewed by two anonymous referees.

\section{References}

Albert, A., Echevin, V., Lévy, M., and Aumont, O.: Impact of nearshore wind stress curl on coastal circulation and primary productivity in the Peru upwelling system, J. Geophys. Res.-Oceans, 115, 1-13, https://doi.org/10.1029/2010JC006569, 2010.

Arístegui, J. and Harrison, W. G.: Decoupling of primary production and community respiration in the ocean: implications for regional carbon studies, Aquat. Microb. Ecol., 29, 199-209, 2002.

Ayón, P., Criales-Hernandez, M. I., Schwamborn, R., and Hirche, H. J.: Zooplankton research off Peru: A review, Prog. Oceanogr., 79, 238-255, https://doi.org/10.1016/j.pocean.2008.10.020, 2008.

Bach, L. T., Paul, A., Boxhammer, T., von der Esch, E., Graco, M., Schulz, K. G., Achterberg, E. P., Aguayo, P., Arístegui Ruiz, J., Ayón, P., Banos, I., Bernales, A., Boegeholz, A. S., Chavez, F. P., Chen, S.-M., Doering, K., Filella, A., Fischer, M. A., Grasse, P., Haunost, M., Hennke, J., Hernandez-Hernandez, N., Hopwood, M., Igarza, M., Kalter, V., Kittu, L., Kohnert, P., Ledesma, J., Lieberum, C., Lischka, S., Löscher, C. R., Ludwig, A., Mendoza, U., Meyer, J., Meyer, J., Minutolo, F., Ortiz Cortes, J., Piiparinen, J., Sforna, C., Spilling, K., Sanchez, S., Spisla, C., Sswat, M., Zavala Moreira, M., and Riebesell, U.: KOSMOS 2017 Peru mesocosm study: overview data, PANGAEA, https://doi.org/10.1594/PANGAEA.923395, 2020.

Bach, L. T., Taucher, J., Boxhammer, T., Ludwig, A., Achterberg, E. P., Algueró-Muñiz, M., Anderson, L. G., Bellworthy, J., Büdenbender, J., Czerny, J., Ericson, Y., Esposito, M., Fischer, M., Haunost, M., Hellemann, D., Horn, H. G., Hornick, T., Meyer, J., Sswat, M., Zark, M., and Riebesell, U.: Influence of Ocean Acidification on a Natural Winter-to-Summer Plankton Succession: First Insights from a Long-Term Mesocosm Study Draw Attention to Periods of Low Nutrient Concentrations, PLoS One, 11, e0159068, https://doi.org/10.1371/journal.pone.0159068, 2016a.

Bach, L. T., Boxhammer, T., Larsen, A., Hildebrandt, N., Schulz, K. G., and Riebesell, U.: Influence of plankton community structure on the sinking velocity of marine aggregates, Global Biogeochem. Cy., 30, 1199-1214, https://doi.org/10.1002/2016GB005372, 2016b.

Bakun, A. and Weeks, S. J.: The marine ecosystem off Peru: What are the secrets of its fishery productivity and what might its future hold?, Prog. Oceanogr., 79, 290-299, https://doi.org/10.1016/j.pocean.2008.10.027, 2008.

Barlow, R. G., Cummings, D. G., and Gibb, S. W.: Improved resolution of mono- and divinyl chlorophylls $\mathrm{a}$ and $\mathrm{b}$ and zeaxanthin and lutein in phytoplankton extracts using reverse phase C-8 HPLC, Mar. Ecol. Prog. Ser., 161, 303-307, https://doi.org/10.3354/meps161303, 1997.

Beranles, A., Sanchez, S., Bach, L. T., Graco, M., Ledesma, J., Chang, F., Franco, A., Walz, K., and Riebesell, U.: Succession of phytoplankton in response to a simulated upwelling event in the Northern Humboldt Current System, in preparation, 2020.

Boxhammer, T., Bach, L. T., Czerny, J., and Riebesell, U.: Technical note: Sampling and processing of mesocosm sediment trap material for quantitative biogeochemical analysis, Biogeosciences, 13, 2849-2858, https://doi.org/10.5194/bg-13-2849-2016, 2016.

Boxhammer, T., Bach, L. T., Sswat, M., and Riebesell, U.: Orni-eutrophication by Inca terns (Larosterna inca) during the KOSMOS study 2017 in the coastal upwelling system off Peru, OceanRep, GEOMAR, https://doi.org/10.3289/ORNI_EUTROPHICATION, 2019. 
Boyd, P. W. and Newton, P. P.: Does planktonic community structure determine downward particulate organic carbon flux in different oceanic provinces?, Deep-Sea Res. Pt. I, 46, 63-91, 1999.

Breitburg, D., Levin, L. A., Oschlies, A., Grégoire, M., Chavez, F. P., Conley, D. J., Garçon, V., Gilbert, D., Gutiérrez, D., Isensee, K., Jacinto, G. S., Limburg, K. E., Montes, I., Naqvi, S. W. A., Pitcher, G. C., Rabalais, N. N., Roman, M. R., Rose, K. A., Seibel, B. A., Telszewski, M., Yasuhara, M., and Zhang, J.: Declining oxygen in the global ocean and coastal waters, Science, 359, 6371, https://doi.org/10.1126/science.aam7240, 2018.

Browning, T. J., Rapp, I., Schlosser, C., Gledhill, M., Achterberg, E. P., Bracher, A., and Le Moigne, F. A. C.: Influence of Iron, Cobalt, and Vitamin B12 Supply on Phytoplankton Growth in the Tropical East Pacific During the 2015 El Niño, Geophys. Res. Lett., 45, 6150-6159, https://doi.org/10.1029/2018GL077972, 2018.

Bruland, K. W., Rue, E. L., Smith, G. J., and DiTullio, G. R.: Iron, macronutrients and diatom blooms in the Peru upwelling regime: Brown and blue waters of Peru, Mar. Chem., 93, 81-103, https://doi.org/10.1016/j.marchem.2004.06.011, 2005.

Brzezinski, M. A.: The Si : C : N ratio of marine Diatoms - interspecific variability and the effect of some environmental variables, J. Phycol., 21, 347-357, 1985.

Carr, M. E.: Estimation of potential productivity in Eastern Boundary Currents using remote sensing, Deep-Sea Res. Pt. II, 49, 5980, https://doi.org/10.1016/S0967-0645(01)00094-7, 2002.

Chavez, F. P. and Messié, M.: A comparison of Eastern Boundary Upwelling Ecosystems, Prog. Oceanogr., 83, 80-96, https://doi.org/10.1016/j.pocean.2009.07.032, 2009.

Chavez, F. P., Pennington, J. T., Castro, C. G., Ryan, J. P., Michisaki, R. P., Schlining, B., Walz, P., Buck, K. R., McFadyen, A., and Collins, C. A.: Biological and chemical consequences of the 1997-1998 El Niño in central California waters, Prog. Oceanogr., 54, 205-232, https://doi.org/10.1016/S0079-6611(02)00050-2, 2002.

Chavez, F. P., Bertrand, A., Guevara-Carrasco, R., Soler, P., and Csirke, J.: The northern Humboldt Current System: Brief history, present status and a view towards the future, Prog. Oceanogr., 79, 95-105, https://doi.org/10.1016/j.pocean.2008.10.012, 2008.

Chen, S.-M., Riebesell, U., Schulz, K. G., von der Esch, E., and Bach, L. T.: Temporal dynamics of sea surface carbonate chemistry in response to natural and simulated upwelling events in the Peruvian oxygen minimum zone, in preparation, 2020.

Chever, F., Rouxel, O. J., Croot, P. L., Ponzevera, E., Wuttig, K., and Auro, M.: Total dissolvable and dissolved iron isotopes in the water column of the Peru upwelling regime, Geochim. Cosmochim. Ac., 162, 66-82, https://doi.org/10.1016/j.gca.2015.04.031, 2015.

Coverly, S., Kérouel, R., and Aminot, A.: A re-examination of matrix effects in the segmented-flow analysis of nutrients in sea and estuarine water, Anal. Chim. Acta, 712, 94-100, https://doi.org/10.1016/j.aca.2011.11.008, 2012.

Czerny, J., Schulz, K. G., Krug, S. A., Ludwig, A., and Riebesell, U.: Technical Note: The determination of enclosed water volume in large flexible-wall mesocosms "KOSMOS", Biogeosciences, 10, 1937-1941, https://doi.org/10.5194/bg-10-1937-2013, 2013.

Daneri, G., Dellarossa, V., Quiñones, R., Jacob, B., Montero, P., and Ulloa, O.: Primary production and community respiration in the Humboldt Current System off Chile and as- sociated oceanic areas, Mar. Ecol. Prog. Ser., 197, 41-49, https://doi.org/10.3354/meps 197041, 2000.

DiTullio, G. R., Geesey, M. E., Mancher, J. M., Alm, M. B., Riseman, S. F., and Bruland, K. W.: Influence of iron on algal community composition and physiological status in the Peru upwelling system, Limnol. Oceanogr., 50, 1887-1907, https://doi.org/10.4319/lo.2005.50.6.1887, 2005.

Franz, J. M. S., Krahmann, G., Lavik, G., Grasse, P., Dittmar, T., and Riebesell, U.: Dynamics and stoichiometry of nutrients and phytoplankton in waters influenced by the oxygen minimum zone in the eastern tropical Pacific, Deep-Sea Res. Pt. I, 62, 20-31, https://doi.org/10.1016/j.dsr.2011.12.004, 2012a.

Franz, J. M. S., Hauss, H., Sommer, U., Dittmar, T., and Riebesell, U.: Production, partitioning and stoichiometry of organic matter under variable nutrient supply during mesocosm experiments in the tropical Pacific and Atlantic Ocean, Biogeosciences, 9, 46294643, https://doi.org/10.5194/bg-9-4629-2012, 2012b.

García-Reyes, M., Sydeman, W. J., Schoeman, D. S., Rykaczewski, R. R., Black, B. A., Smit, A. J., and Bograd, S. J.: Under Pressure: Climate Change, Upwelling, and Eastern Boundary Upwelling Ecosystems, Front. Mar. Sci., 2, 1-10, https://doi.org/10.3389/fmars.2015.00109, 2015.

Garreaud, R. D.: A plausible atmospheric trigger for the 2017 coastal El Niño, Int. J. Climatol., 38, e1296-e1302, https://doi.org/10.1002/joc.5426, 2018.

González, H. E., Daneri, G., Iriarte, J. L., Yannicelli, B., Menschel, E., Barría, C., Pantoja, S., and Lizárraga, L.: Carbon fluxes within the epipelagic zone of the Humboldt Current System off Chile: The significance of euphausiids and diatoms as key functional groups for the biological pump, Prog. Oceanogr., 83, 217-227, https://doi.org/10.1016/j.pocean.2009.07.036, 2009.

Graco, M. I., Purca, S., Dewitte, B., Castro, C. G., Morón, O., Ledesma, J., Flores, G., and Gutiérrez, D.: The OMZ and nutrient features as a signature of interannual and low-frequency variability in the Peruvian upwelling system, Biogeosciences, 14, 4601-4617, https://doi.org/10.5194/bg-14-4601-2017, 2017.

Gruber, N.: Warming up, turning sour, losing breath: ocean biogeochemistry under global change, Philos. T. Roy. Soc. A-Mat., 369, 1980-1996, https://doi.org/10.1098/rsta.2011.0003, 2011.

Hansen, H. P. and Koroleff, F.: Determination of nutrients, in Methods of Seawater Analysis, edited by: Grasshoff, K., Kremling, K., and Ehrhardt, M., Wiley-VCH, Weinheim, Germany, 159226, 1999.

Holm-Hansen, O., Amos, A. F., and Hewes, C. D.: Reliability of estimating chlorophyll a concentrations in Antarctic waters by measurement of in situ chlorophyll a fluorescence, Mar. Ecol. Prog. Ser., 196, 103-110, https://doi.org/10.3354/meps196103, 2000.

Hutchins, D. A., Hare, C. E., Weaver, R. S., Zhang, Y., Firme, G. F., DiTullio, G. R., Alm, M. B., Riseman, S. F., Maucher, J. M., Geesey, M. E., Trick, C. G., Smith, G. J., Rue, E. L., Conn, J., and Bruland, K. W.: Phytoplankton iron limitation in the Humboldt Current and Peru Upwelling, Limnol. Oceanogr., 47, 997-1011, https://doi.org/10.4319/lo.2002.47.4.0997, 2002.

Igarza, M., Sanchez, S., Bernales, A., Gutierrez, D., Meyer, J., Riebesell, U., Graco, M. I., Bach, L. T., Dittmar, T., and Niggemann, J.: Dissolved organic matter production during an artificially-induced red tide off central Peru, in preparation, 2020. 
Jackson, G. A.: A model of the formation of marine algal flocs by physical coagulation processes, Deep-Sea Res. Pt. A, 37, 1197$1211,1990$.

Karstensen, J., Stramma, L., and Visbeck, M.: Oxygen minimum zones in the eastern tropical Atlantic and Pacific oceans, Prog. Oceanogr., 77, 331-350, https://doi.org/10.1016/j.pocean.2007.05.009, 2008.

Kérouel, R. and Aminot, A.: Fluorometric determination of ammonia in sea and estuarine waters by direct segmented flow analysis, Mar. Chem., 57, 265-275, https://doi.org/10.1016/S03044203(97)00040-6, 1997.

Klausmeier, C. A., Litchman, E., Daufrense, T., and Levin, S. A.: Optimal nitrogen-to-phosphorus stoichiometry of phytoplankton, Nature, 429, 171-174, https://doi.org/10.1038/nature02454, 2004.

Kudela, R. M., Seeyave, S., and Cochlan, W. P.: The role of nutrients in regulation and promotion of harmful algal blooms in upwelling systems, Prog. Oceanogr., 85, 122-135, https://doi.org/10.1016/j.pocean.2010.02.008, 2010.

Laws, E. A. and Maiti, K.: The relationship between primary production and export production in the ocean: Effects of time lags and temporal variability, Deep-Sea Res. Pt. I, 148, 100-107, https://doi.org/10.1016/j.dsr.2019.05.006, 2019.

Longhurst, A.: Seasonal cycles of pelagic production and consumption, Prog. Oceanogr., 36, 77-167, https://doi.org/10.1016/00796611(95)00015-1, 1995.

Mackey, M. D., Mackey, D. J., Higgins, H. W., and Wright, S. W.: CHEMTAX - a program for estimating class abundances from chemical markers: application to HPLC measurements of phytoplankton, Mar. Ecol. Prog. Ser., 144, 265-283, 1996.

Messié, M. and Chavez, F. P.: Seasonal regulation of primary production in eastern boundary upwelling systems, Prog. Oceanogr., 134, 1-18, https://doi.org/10.1016/j.pocean.2014.10.011, 2015.

Meyer, J., Löscher, C. R., Lavik, G., and Riebesell, U.: Mechanisms of $\mathrm{P}^{*}$ Reduction in the Eastern Tropical South Pacific, Front. Mar. Sci., 4, 1-12, https://doi.org/10.3389/fmars.2017.00001, 2017.

Morris, A. W. and Riley, J. P.: The determination of nitrate in sea water, Anal. Chim. Acta, 29, 272-279, 1963.

Mullin, J. B. and Riley, J. P.: The colorimetric determination of silicate with special reference to sea and natural waters, Anal. Chim. Acta, 12, 162-176, https://doi.org/10.1016/S00032670(00)87825-3, 1955

Murphy, J. and Riley, J. P.: A modified single solution method for the determination of phosphate in natural waters, Anal. Chim. Acta, 27, 31-36, https://doi.org/10.1016/S0003-2670(00)88444$5,1962$.

Otero, X. L., De La Peña-Lastra, S., Pérez-Alberti, A., Ferreira, T. O., and Huerta-Diaz, M. A.: Seabird colonies as important global drivers in the nitrogen and phosphorus cycles, Nat. Commun., 9, 246, https://doi.org/10.1038/s41467-017-02446-8, 2018.

Paul, A. J., Bach, L. T., Schulz, K.-G., Boxhammer, T., Czerny, J., Achterberg, E. P., Hellemann, D., Trense, Y., Nausch, M., Sswat, M., and Riebesell, U.: Effect of elevated $\mathrm{CO}_{2}$ on organic matter pools and fluxes in a summer Baltic Sea plankton community, Biogeosciences, 12, 6181-6203, https://doi.org/10.5194/bg-126181-2015, 2015.

Quigg, A., Finkel, Z. Z. V, Irwin, A. J. A., Rosenthal, Y., Ho, T.-Y., Reinfelder, J. R., Schofield, O., Morel, F. M. M., and
Falkowski, P. G.: The evolutionary inheritance of elemental stoichiometry in marine phytoplankton, Nature, 425, 291-294, https://doi.org/10.1038/nature01953, 2003.

Rapp, I., Schlosser, C., Rusiecka, D., Gledhill, M., and Achterberg, E. P.: Automated preconcentration of Fe, Zn, $\mathrm{Cu}, \mathrm{Ni}, \mathrm{Cd}, \mathrm{Pb}, \mathrm{Co}$, and $\mathrm{Mn}$ in seawater with analysis using high-resolution sector field inductively-coupled plasma mass spectrometry, Anal. Chim. Acta, 976, 1-13, https://doi.org/10.1016/j.aca.2017.05.008, 2017.

Riebesell, U., Czerny, J., von Bröckel, K., Boxhammer, T., Büdenbender, J., Deckelnick, M., Fischer, M., Hoffmann, D., Krug, S. A., Lentz, U., Ludwig, A., Muche, R., and Schulz, K. G.: Technical Note: A mobile sea-going mesocosm system - new opportunities for ocean change research, Biogeosciences, 10, 18351847, https://doi.org/10.5194/bg-10-1835-2013, 2013.

Schulz, K. G. and Riebesell, U.: Diurnal changes in seawater carbonate chemistry speciation at increasing atmospheric carbon dioxide, Mar. Biol., 160, 1889-1899, 2013.

Schulz, K. G., Bach, L. T., Bellerby, R., Bermudez, R., Boxhammer, T., Czerny, J., Engel, A., Ludwig, A., Larsen, A., Paul, A., Sswat, M., and Riebesell, U.: Phytoplankton blooms at increasing levels of atmospheric carbon dioxide: experimental evidence for negative effects on prymnesiophytes and positive on small picoeukaryotes, Front. Mar. Sci., 4, 1-18, https://doi.org/10.3389/fmars.2017.00064, 2017.

Sharp, J. H.: Improved analysis for "particulate" organic carbon and nitrogen from seawater, Limnol. Oceanogr., 19, 984-989, 1974.

Smayda, T. J. and Trainer, V. L.: Dinoflagellate blooms in upwelling systems: Seeding, variability, and contrasts with diatom bloom behaviour, Prog. Oceanogr., 85, 92-107, https://doi.org/10.1016/j.pocean.2010.02.006, 2010.

Spilling, K., Camarena-Gómez, M. T., Lipsewers, T., MartinezVarela, A., Díaz-Rosas, F., Eronen-Rasimus, E., Silva, N., von Dassow, P., and Montecino, V.: Impacts of reduced inorganic $\mathrm{N}: \mathrm{P}$ ratio on three distinct plankton communities in the Humboldt upwelling system, Mar. Biol., 166, 1-17, https://doi.org/10.1007/s00227-019-3561-x, 2019.

Stange, P., Bach, L. T., Le Moigne, F. A. C., Taucher, J., Boxhammer, T., and Riebesell, U.: Quantifying the time lag between organic matter production and export in the surface ocean: Implications for estimates of export efficiency, Geophys. Res. Lett., 44, 268-276, https://doi.org/10.1002/2016GL070875, 2017.

Sterner, R. W., Andersen, T., Elser, J. J., Hessen, D. O., Hood, J. M., McCauley, E., and Urabe, J.: Scale-dependent carbon: Nitrogen: phosphorus seston stoichiometry in marine and freshwaters, Limnol. Oceanogr., 53, 1169-1180, https://doi.org/10.4319/lo.2008.53.3.1169, 2008.

Stramma, L., Schmidtko, S., Levin, L. A., and Johnson, G. C.: Ocean oxygen minima expansions and their biological impacts, Deep-Sea Res. Pt. I, 57, 587-595, https://doi.org/10.1016/j.dsr.2010.01.005, 2010.

Stramma, L., Bange, H. W., Czeschel, R., Lorenzo, A., and Frank, M.: On the role of mesoscale eddies for the biological productivity and biogeochemistry in the eastern tropical Pacific Ocean off Peru, Biogeosciences, 10, 7293-7306, https://doi.org/10.5194/bg-10-7293-2013, 2013.

Takahashi, K. and Martínez, A. G.: The very strong coastal El Niño in 1925 in the far-eastern Pacific, Clim. Dynam., 52, 7389-7415, 2019. 
Taucher, J., Bach, L. T., Boxhammer, T., Nauendorf, A., Achterberg, E. P., Algueró-Muñiz, M., Arístegui, J., Czerny, J., Esposito, M., Guan, W., Haunost, M., Horn, H. G., Ludwig, A., Meyer, J., Spisla, C., Sswat, M., Stange, P., and Riebesell, U.: Influence of Ocean Acidification and Deep Water Upwelling on Oligotrophic Plankton Communities in the Subtropical North Atlantic: Insights from an In situ Mesocosm Study, Front. Mar. Sci., 4, 1-18, https://doi.org/10.3389/fmars.2017.00085, 2017.

Terry, K. L., Hirata, J., and Laws, E. A.: Light-limited growth of two strains of the marine diatom Phaeodactylum tricornutum Bohlin: Chemical composition, carbon partitioning and the diel periodicity of physiological processes, J. Exp. Mar. Bio. Ecol., 68, 209227, https://doi.org/10.1016/0022-0981(83)90054-0, 1983.

Thiel, M., Macaya, E. C., Acuña, E., Arntz, W. E., Bastias, H., Brokordt, K., Camus, P. A., Castilla, J. C., Castro, L. R., Cortés, M., Dumont, C. P., Escribano, R., Fernández, M., Gajardo, J. A., Gaymer, C. F., Gomez, I., González, A. E., González, H. E., Haye, P. A., Illanes, J.-E., Iriarte, J. L., Lancellotti, D. A., LunaJorquera, G., Luxoro, C., Manríquez, P. H., Marín, V., Muñoz, P., Navarrete, S. A., Perez, E., Poulin, E., Sellanes, J., Sepúlveda, H. H., Stotz, W., Tala, F., Thomas, A., Vargas, C. A., Vasquez, J. A., and Alonso Vega, J. M.: The Humboldt Current System of Northern and Central Chile: Oceanographic Processes, Ecological Interactions and Socioeconomic Feedback, Oceanogr. Mar. Biol. An Annu. Rev., 45, 195-344, 2007.
Thompson, M. and Wood, R.: Harmonized guidelines for internal quality control in analytical chemistry laboratories, in: Pure and Applied Chemistry, edited by: Burrows, H. and Stohner, J., IUPAC, UK, 649-666, 1995.

Wassmann, P.: Retention versus export food chains: processes controlling sinking loss from marine pelagic systems, Hydrobiologia, 363, 29-57, 1997. 